\title{
Dynamic modeling and control of a proton exchange membrane fuel cell as a distributed generator
}

\author{
Padmanabhan Srinivasan \\ West Virginia University
}

Follow this and additional works at: https://researchrepository.wvu.edu/etd

\section{Recommended Citation}

Srinivasan, Padmanabhan, "Dynamic modeling and control of a proton exchange membrane fuel cell as a distributed generator" (2003). Graduate Theses, Dissertations, and Problem Reports. 1399.

https://researchrepository.wvu.edu/etd/1399

This Thesis is protected by copyright and/or related rights. It has been brought to you by the The Research Repository @ WVU with permission from the rights-holder(s). You are free to use this Thesis in any way that is permitted by the copyright and related rights legislation that applies to your use. For other uses you must obtain permission from the rights-holder(s) directly, unless additional rights are indicated by a Creative Commons license in the record and/ or on the work itself. This Thesis has been accepted for inclusion in WVU Graduate Theses, Dissertations, and Problem Reports collection by an authorized administrator of The Research Repository @ WVU. For more information, please contact researchrepository@mail.wvu.edu. 


\title{
Dynamic Modeling and Control of a Proton Exchange Membrane Fuel Cell as a Distributed Generator
}

\author{
by \\ Padmanabhan Srinivasan

\begin{abstract}
Thesis submitted to the
College of Engineering and Mineral Resources

at West Virginia University

in partial fulfillment of the requirements

for the degree of

Masters of Science in Mechanical Engineering
\end{abstract}

\author{
Dr. Ali Feliachi \\ Dr. Samir Shoukry \\ Dr. John E. Sneckenberger, Chair
}

Department of Mechanical and Aerospace Engineering

Morgantown, West Virginia

2003

Keywords: PEM Fuel Cells, Stack Temperature, Dynamic Modeling, Cascade Controls, Power Electronics 


\section{ABSTRACT \\ Dynamic Modeling and Control of a Proton Exchange Membrane Fuel Cell as a Distributed Generator}

\section{Padmanabhan Srinivasan}

The role of distributed generators in a deregulated electric power system will be very significant in the near future. Fuel cells, as distributed generators, are a promising technology. Fuel cells are known for their reliability, power quality, eco-friendly nature and fuel efficiency. This research is part of the project on "Integrated Computing, Communication and Distributed Control of Deregulated Electric Power Systems" conducted at West Virginia University, and sponsored by the USDOE-EPSCoR Program.

This research concentrated on the modeling and control of a Proton Exchange Membrane (PEM) fuel cell in a deregulated electric power system. The PEM fuel cell is a Multiple Input Multiple Output (MIMO) system with various dynamic states. In most previous model studies, the stack temperature of a fuel cell was considered to be constant. For long duration short transient and analysis, the stack temperature should be considered a variable. A derived dynamic model for the PEM fuel cell was analyzed using MATLAB/SIMULINK. Power generation characteristics of the PEM fuel cell were presented. Performance of the PEM fuel cell under various operating conditions was analyzed.

Output power from a PEM fuel cell is DC power. In order to interface the PEM fuel cell with the electric utility grid, its output has to meet the voltage and frequency specifications specified by IEEE Standards. The Power Conditioning Unit (PCU) is a device that conditions the output power from the PEM fuel cell such that it is suitable for interfacing with the $117 \mathrm{~V}$ 
RMS, $60 \mathrm{~Hz}$, three phase electric utility grid. The PCU in this thesis was designed considering the PEM fuel cell to be a voltage source on the electric utility grid. The PCU results using MATLAB/Simulink were presented.

Controller design is the key to operating the PEM fuel cell under the load-following mode of operation. A local Proportional (P) controller within the PCU environment was designed to meet the load demand changes. A cascade control scheme to control the fuel flow rate and modulating amplitude was then designed to meet voltage requirements. Fuel flow rate was considered as the primary control variable and modulating amplitude is considered as the secondary control variable.

The three primary goals of this research were to develop a design model a PEM fuel cell with variable temperature, model the PCU and to develop a control system for better performance when the PEM fuel cell operates in a deregulated electric power system. 
Dedicated to the love and affection of my parents. 


\section{ACKNOWLEDGEMENTS}

First of all, I would like to thank the Almighty for everything he has given to me. I would like to thank my parents for their love and affection. They taught me what it what it takes to be a successful person in this world.

I would like to thank Dr. John Ed Sneckenberger for his valuable guidance and support he has extended throughout the period of my thesis work. Without his encouragement and motivation, this thesis would have been nowhere possible.

I appreciate the efforts of my committee members, Dr. Ali Feliachi and Dr. Samir Shoukry, for their suggestions and review on my thesis. I also would like to thank Mr. Robert Mills for sharing his Power Electronics expertise.

I thank the USDOE-EPSCoR program for their financial support of this research. 


\section{TABLE OF CONTENTS}

$\begin{array}{lr}\text { ABSTRACT } & \text { ii } \\ \text { ACKNOWLEDGEMENTS } & \mathrm{v} \\ \text { TABLE OF CONTENTS } & \text { vi } \\ \text { LIST OF FIGURES } & \text { viii } \\ \text { LIST OF TABLES } & \mathrm{x} \\ \text { Chapter } 1 . \text { Introduction } & 1 \\ 1.1 \quad \text { Deregulated Electric Utility System } & 1 \\ 1.2 \quad \text { Distributed Generation } & 2 \\ 1.3 \quad \text { Research Objectives } & 2\end{array}$

Chapter 2. Assessment of Distributed Generators with Respect to Energy Market and Energy Management

2.1 Introduction to DG Technologies

2.2 Types of Fuel Cells for Distributed Generation Applications 4

2.3 Advantages of a PEM Fuel Cell 5

2.4 Disadvantages of a PEM Fuel Cell $\quad 7$

Chapter 3. Literature Review $\quad 8$

$3.1 \quad$ Fuel Cells Assessment $\quad 8$

3.2 PEM Fuel Cell Temperature Modeling $\quad 8$

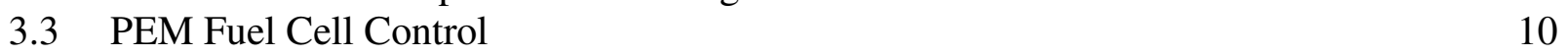

Chapter 4. Problem Statement and Approach 11

4.1 Various Issues dealt with in Thesis 11

4.2 Dynamic Modeling of a PEM Fuel Cell with Variable Stack Temperature 11

4.3 Modeling of PCU 12

4.4 Design of Controllers $\quad 13$

4.4.1 Local Controller for PCU 13

4.4.2 Global Controller for PEM Fuel Cell System 13

Chapter 5. Dynamic Modeling of a PEM Fuel Cell 15

$5.1 \quad$ Introduction $\quad 15$

5.2 Dynamic Modeling Approach $\quad 15$

5.3 Dynamic Modeling Assumptions 16

$\begin{array}{lll}5.4 & \text { Stack Configuration Details } & 16\end{array}$

$\begin{array}{lll}5.5 & \text { Equations used in Modeling } & 18\end{array}$

$\begin{array}{lll}\text { 5.5.1 Overall Chemical Reaction } & 18\end{array}$

5.5.2 Energy Balance Equation for a PEM Fuel Cell 19

$\begin{array}{ll}\text { 5.5.3 Component Balance Equation } & 19\end{array}$

$\begin{array}{lll}5.5 .4 & \text { Nernst Equation } & 20\end{array}$

5.5.5 Total Heat Generated in a PEM Fuel Cell 21

5.5.6 Variation of Specific Heat for Ideal Gases with Changes in Temperature 21

5.5.7 Cross Section Temperature and Heat Generated Relationship 21 
5.5.8 Total Heat Generated and Cell Heat Relationship 22

5.6 PEM Fuel Cell Model 22

5.6.1 PEM Fuel Cell Non-linear Model 22

5.6.2 PEM Fuel Cell Linear Model 22

5.6.2.1 Introduction $\quad 22$

5.6.2.2 Hydrogen Component Balance Transfer Function 23

5.6.2.3 Voltage Transfer Function 24

5.6.2.4 PEM Fuel Cell Transfer Function 25

Chapter 6. Power Conditioning Unit for PEM Fuel Cell 26

$\begin{array}{lll}6.1 & \text { Introduction } & 26\end{array}$

6.2 DC-AC Inverter 26

Chapter 7. PEM Fuel Cell Control System 29

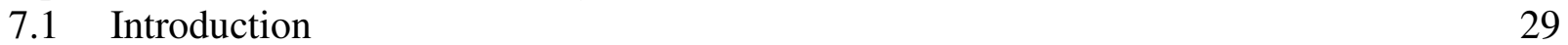

7.2 Cascade Control for PEM Fuel Cell 29

7.3 Master Controller for PI Control of Fuel Flow Rate in PEM Fuel Cell 31

7.4 Slave Controller for P Control of Modulating Amplitude of PCU 33

Chapter 8. Results and Discussion $\quad 34$

8.1 PEM Fuel Cell Characteristics 34

8.2 Temperature Dynamics for the PEM Fuel Cell 36

8.3 Linear PEM Fuel Cell System Model Control Results 39

8.4 Results Summary 40

Chapter 9. Contributions and Recommendations 43

$\begin{array}{lll}9.1 & \text { Contributions } & 43\end{array}$

$\begin{array}{lll}9.2 & \text { Achievements } & 44\end{array}$

9.3 Future Research 45

$\begin{array}{ll}\text { REFERENCES } & 46\end{array}$

Appendix A. PEM Fuel Cell Non-linear Modeling using Simulink 49

Appendix B. PEM Heat Transfer and Temperature Distribution Modeling using MATLAB Programming 52

Appendix C. PEM Fuel Cell Control using Simulink 55

Appendix D. PEM Fuel Cell System 57

D.1 Introduction $\quad 57$

$\begin{array}{lll}\text { D.2 } & \text { Humidifier } & 59\end{array}$

$\begin{array}{lll}\text { D.3 Reformer } & 60\end{array}$

D.4 Hydrogen Buffer Tank 61 


\section{LIST OF FIGURES}

Figure 5.1: Cross-Sectional View of a Schematic PEM Unit Fuel Cell

Figure 5.2: Top View of a Schematic PEM Unit Fuel Cell 17

Figure 5.3: Linearized PEM Fuel Cell Model Block Diagram 23

Figure 5.4: PEM Fuel Cell Output under Specified Operating Conditions 24

Figure 7.1: Simulink Diagram for PEM Fuel Cell Control 30

Figure 7.2: Root Locus for PEM Fuel Cell 31

Figure 7.3: Bode Plot for PEM Fuel Cell 32

Figure 8.1: PEM Output Voltage Vs Line Current 34

Figure 8.2: PEM Output Voltage Vs Line Current with Various Power Levels 35

Figure 8.3: PEM Output Power Vs Line Current 35

Figure 8.4: Step Change in Input Line Current Vs Time 36

Figure 8.5: Stack Temperature Distribution across Stack Cross Sections Over a Time Period of 4200 secs 37

Figure 8.6: Stack Temperature Response due to Change in Input Line Current 37

Figure 8.7: Stack Output Voltage Response due to Change in Input Line Current and Stack Temperature

Figure 8.8: Stack Output Voltage Response During 200-350 secs due to Change in Line Current and Stack Temperature $\quad 38$

Figure 8.9: PEM Output DC Voltage Response without Controller 39

Figure 8.10: PEM Output DC Voltage Response with PI Controller 40

Figure 8.11: PCU Output AC Voltage Vs Time 41

Figure A.1: Non-linear Model for a PEM Fuel Cell in Simulink 49 
Figure A.2: Voltage and Current Calculations in Simulink

Figure A.3: Entropy Calculations in Simulink

Figure A.4: Mole Fraction Calculations in Simulink

Figure C.1: Linear PEM Fuel Cell System Model Using Simulink

Figure C.2: PCU Model in Simulink

Figure C.3: Inverter Model in Simulink

Figure D.1: Schematic Diagram of a PEM Fuel Cell System 58

Figure D.2: Schematic Diagram of a Humidifier for a PEM Fuel Cell 60

Figure D.3: Schematic Diagram of a Hydrogen Buffer Tank 


\section{LIST OF TABLES}

Table 2.1: Comparison of Different Types of Fuel Cells 6

Table 5.1: PEM Fuel Cell Stack Configuration Details 18

Table 5.2: Operating Conditions for Linearized PEM Fuel Cell Model 23

Table D.1: Conditions for Humidifier ON/OFF Stages 60 


\section{Chapter 1. Introduction}

\subsection{Deregulated Electric Utility System}

Electric utility systems have been under regulatory conditions in the past [1]. Recent developments in customer demand, environmental consciousness and technology developments have paved the way for deregulation in some of the electric utility industry.

Some customers are no longer left without a choice. They can now choose from which source their electric power comes. When regulated, utilities were typically large companies with wide infrastructures. In a deregulated environment, the electric power supplier need not be a large supplier but can be a small retailer. Customers will be able to bid the electricity price and choose the price that best suits them. Customers also have the option of generating their own electricity and selling the excess that's being produced. Emphasis for greener sources of power can be made and it purely lies under their own discretion.

Small generators that have a power capacity from 5 kilowatts to a few megawatts are called distributed generators (DGs). DGs can operate independently as power sources, in conjunction with the electric utility grid in peak saving applications or as auxiliary power sources.

Deregulation calls for restructuring and reconstructing of the electricity market on a wider basis. New technologies have to be tested for reliability. A network of alternate fuel suppliers have to be established on a uniform and wider basis. Electric grid compatibility issues have to be addressed and, finally, deregulation calls for universal codes and standards. 


\subsection{Distributed Generation}

Distributed generation has the capability of decentralizing the electric utility market. Issues such as reliability, power quality, electricity costs and emissions have become very important [2]. In California during the summer of 2000, demand reached very high heights while the power generation level was far lower than the demand [3]. The utility was unable to supply power as per the contracted rates; the customer had to pay nearly double the price per kWh than what they usually paid. Power failures were frequent and the power supplied was below electric utility industry standards. The California crisis looks like a foreteller of the future. Distributed generation could very well be the solution for the above problem.

Various options for DGs are available. Diesel generators, micro turbines, wind turbines and fuel cells are some of the options available. The distributed generator that most suits the need must be selected. Modeling of these distributed generators must be pursued and they should be controlled to follow the load. The goal of this research will be to perform the modeling and control for a particular distributed generator in a deregulated electric power system.

Fuel cells are known for their high efficiency and eco-friendly nature. Fuel cells have found themselves in a wide range of applications such as power sources in automobiles, distributed generators in an electric utility grid and applications in space programs. As a distributed generator, a fuel cell can be used in a stand-alone mode or electric utility grid integrated mode using a Power Conditioning Unit.

\subsection{Research Objectives}

Having discussed the importance of distributed generators and fuel cells, a fuel cell that suits stationary application has to be selected. Then, the fuel cell has to be modeled such that it 
simulates the performance of a real fuel cell. The fuel cell has to be able to get connected with the electric utility grid and also the fuel cell should be able to control its output as the power demand from the electric utility grid changes with time. The five main research objectives for this thesis are enlisted below.

1. Identifying a particular type of fuel cell that serves the need of deregulated electric power systems.

2. Modeling the identified fuel cell, in particular, model the stack temperature as a variable.

3. Modeling of a Power Conditioning Unit that will be able to deliver power to the electric utility grid from the fuel cell in an usable form.

4. Designing suitable controllers for the desired performance of the fuel cell system if it were connected to the electric utility grid.

5. Analyzing the fuel cell system through simulations. 


\section{Chapter 2. Assessment of Distributed Generators with Respect to Energy Market and Energy Management}

\subsection{Introduction to DG Technologies}

Based on various factors such as efficiency and eco-friendliness, fuel cells were selected as the DG appropriate for this research. Fuel cells are well suited for a deregulated electric power system. They are compact compared to the other DGs such as wind turbines and diesel generators. The noise levels are much lower compared to other DGs. PEM fuel cells are very safe to operate and satisfy IEEE 519 standard for electric power quality. A fuel cell can supply power without power surges or dips. It has a design life of 15 years. Its design requires maintenance once in 8000 hours of operating time.

Fuel cells are economical to use. The cost of operating the fuel cell is much lesser than buying electrical power from the utilities. The cost of a fuel cell per $\mathrm{kW}$ is much less than the cost of other DGs such as microturbines and wind turbines [2]. The most important feature of a fuel cell is its eco-friendly nature. It has emission levels far less than conventional DGs such as diesel engines. Carbon monoxide, sulphur oxide and nitrogen oxide emission levels are near zero.

\subsection{Types of Fuel Cells for Distributed Generation Applications}

As one of the options for distributed generation, a fuel cell that would serve in a loadfollowing mode was preferred. This fuel cell must serve as a stationary power generator [3]. It 
was intended for use in industrial and domestic markets to generate power on its own and utility power could be used as a back up generator.

The fuel cell chosen for this type of application must provide competitive, reliable and quality power without emitting pollutants such as oxides of nitrogen, carbon or sulphur. It must respond quickly to changes in load, must have less maintenance and must have a longer cell life compared to other types of fuel cells.

The various types of fuel cells available are the Proton Exchange Membrane (PEM) Fuel Cell, Alkaline Fuel Cell (AFC), Phosphoric Acid Fuel Cell (PAFC), Molten Carbonate Fuel Cell (MCFC) and Solid Oxide Fuel Cell (SOFC). Various factors about the different types of fuel cells are tabulated in Table 2.1 based on information in Reference 4. Those factors were compared and then the PEM Fuel Cell was chosen for the load-following application.

\subsection{Advantages of a PEM Fuel Cell}

The ten main advantages of PEM fuel cells in general and in comparison with other fuel cells are as follows:

1. Electrolyte used in a PEM fuel cell is a solid one and has no liquids that are usually corrosive, except for water. This means less corrosion and longer cell life.

2. PEM fuel cells are low temperature fuel cells. The operating temperature could be reached fast. The start-up time for a PEM fuel cell is considerably less compared to other fuel cells.

3. PEM fuel cell responds quicker to changes in power demand.

4. As the operating temperature is low, there is no need for special materials in the design of the fuel cell.

5. Low maintenance costs. 
Table 2.1: Comparison of Different Types of Fuel Cells

\begin{tabular}{|c|c|c|c|c|c|}
\hline & PEM & AFC & PAFC & MCFC & SOFC \\
\hline Electrolyte & $\begin{array}{l}\text { Flourinated } \\
\text { Sulfonic Acid } \\
\text { (solid) }\end{array}$ & $\begin{array}{l}\text { KOH } \\
\text { absorbed in } \\
\text { asbestos } \\
\text { (liquid) }\end{array}$ & $\begin{array}{l}\mathrm{H}_{2} \mathrm{PO}_{5}(100 \% \text { ) in } \\
\mathrm{SiC} \text { (liquid) }\end{array}$ & $\begin{array}{l}\text { Combination of alkali } \\
\text { carbonates in a ceramic } \\
\text { matrix of } \mathrm{LiAlO}_{2} \text { (liquid) }\end{array}$ & $\begin{array}{l}\mathrm{Y}_{2} \mathrm{O}_{3} \text { (solid) or } \\
\text { stabilized } \mathrm{ZrO}_{2}\end{array}$ \\
\hline $\begin{array}{l}\text { Operating } \\
\text { Temperature }\end{array}$ & $180^{\circ} \mathrm{F}$ & $250^{\circ} \mathrm{F}$ & $300^{\circ} \mathrm{F}-480^{\circ} \mathrm{F}$ & $1100^{\circ} \mathrm{F}-1300^{\circ} \mathrm{F}$ & $1800^{\circ} \mathrm{F}$ \\
\hline $\begin{array}{l}\text { Start Up } \\
\text { Time }{ }^{\infty}\end{array}$ & Small & Moderate & Moderate & High & High \\
\hline Cogeneration & Not Possible & $\begin{array}{l}\text { Not Possible } \\
\text { at low conc. }\end{array}$ & Possible & Possible & Possible \\
\hline $\begin{array}{l}\text { Charge } \\
\text { Carier }\end{array}$ & $\mathrm{H}^{+}$ & $\mathrm{OH}^{-}$ & $\mathrm{H}^{+}$ & $\mathrm{CO}_{3}{ }^{-2}$ & $\mathrm{O}^{-2}$ \\
\hline Catalyst & $\mathrm{Pt}$ & $\mathrm{Ni}, \mathrm{Ag}$ & $\mathrm{Pt}$ & $\begin{array}{l}\text { Ni(anode) } \\
\text { Nickel oxide (cathode) }\end{array}$ & $\begin{array}{l}\mathrm{Co}-\mathrm{ZrO}_{2} / \mathrm{Ni}-\mathrm{ZrO}_{2} \\
\text { (anode) } \\
\text { Sr-doped } \mathrm{LaMnO}_{3} \\
\text { (cathode) }\end{array}$ \\
\hline Advantages & $\begin{array}{l}\text { *No Corrosion } \\
\left.\text { (Only } \mathrm{H}_{\mathrm{P}} \mathrm{O}\right) \\
\text { *Cormpact } \\
\text { *Faster startup } \\
\text { *Longer nunning } \\
\text { time }\end{array}$ & & $\begin{array}{l}\text { *Water management } \\
\text { is easy } \\
{ }^{*} \mathrm{H}_{2} \mathrm{PO}_{5} \text { minimizes } \\
\text { water vapor } \\
\text { pressure } \\
{ }^{*} \mathrm{CO}_{2} \text { doesn't react } \\
\text { with electrolytes }\end{array}$ & $\begin{array}{l}\text { *Rejected he at enough to } \\
\text { drive a turbine } \\
\text { *Can be used for } \\
\text { Co-Generation }\end{array}$ & $\begin{array}{l}\text { * Rejected he at enough } \\
\text { to drive a turbine } \\
\text { *Car be used for } \\
\text { Co-Generation }\end{array}$ \\
\hline Disadvantages & $\begin{array}{l}\text { *Lot of care } \\
\text { should be taken to } \\
\text { manage water }\end{array}$ & $\begin{array}{l}\text { *Substantial } \\
\text { cost } \\
\text { associated } \\
\text { with } \\
\text { purification }\end{array}$ & $\begin{array}{l}\text { *Platinum }(\mathrm{Pt}) \\
\text { poisoning by } \mathrm{CO}\end{array}$ & $\begin{array}{l}\text { *High temperature leads } \\
\text { to increased mainterance } \\
\text { and reduced cell life }\end{array}$ & $\begin{array}{l}\text { * High temperature } \\
\text { leads to increased } \\
\text { maintenance and } \\
\text { reduced cell life }\end{array}$ \\
\hline
\end{tabular}

$\oplus$ - Compared to other Fuel Cells 
6. No harmful gases such as Nox, Sox and Cox are released.

7. The water rejected is in the form of a liquid. It is sufficiently hot, so that it could be be used as hot water or could be used to heat room spaces.

8. Capable of operating at pressures up to $2900 \mathrm{psi}$.

9. Low noise levels.

10. PEM fuel cells lead other types of fuel cells in terms of market commercialization.

\subsection{Disadvantages of a PEM Fuel Cell}

Though the PEM fuel cell has a lot of advantages, it has its own disadvantages. The three main disadvantages are as follows:

1. The Platinum $(\mathrm{Pt})$ catalyst used is costly.

2. The input air should be devoid of carbon monoxide (CO). CO binds itself to Pt and reduces the hydrogen chemisorption.

3. The management of water is very important in increasing the overall efficiency of the fuel cell. Care should be taken to manage water inside the fuel cell. 


\section{Chapter 3. Literature Review}

\subsection{Fuel Cells Assessment}

The Fuel Cell Handbook [5] published by the National Energy Technology Laboratory (NETL) provides a good technology update on fuel cells. This particular information was critical in assessing the various types of fuel cells available today and choosing the right type of fuel cell pertinent to this research. The Fuel Cell Handbook discusses the technology overview, fuel cell performance aspects from a thermodynamic stand point, about various types of fuel cells available such as the Alkaline Fuel Cells (AFC), Phosphoric Acid Fuel Cell (PAFC), Molten Carbonate Fuel Cell (MCFC), Solid Oxide Fuel Cell (SOFC) and Proton Exchange Membrane (PEM) Fuel Cell.

\subsection{PEM Fuel Cell Temperature Modeling}

In the literature, fuel cell models were available for many steady state cases and also for some dynamic cases. This thesis developed a dynamic model for PEM fuel cell. Most models available used the Nernst equation to calculate the cell voltage $[6,7,8]$. The conservation of chemical species equation was used in calculating the molarity/mole fraction of various gas species $[9,10]$. The operating temperature was assumed to be a constant in most of the models. Modeling with a constant operating temperature condition was valid through steady state conditions and for analysis within a small period of time. In reality, the operating temperature changes dynamically, affects the output current and eventually the output power of a fuel cell. 
Models with constant temperature conditions cannot predict the PEM fuel cell performance for longer durations of time. For long duration of time the fuel cell stack temperature increases with time and it eventually affects the output of the fuel cell. To improve this situation, the operating temperature of the fuel cell was considered a variable and was then treated as a variable throughout the PEM fuel cell study in this thesis. There are certain models that predict fuel cell performance under varying temperature conditions. They involve a lot of equations and are mostly modeled using the Computational Fluid Dynamics (CFD) approach. This modeling approach $[12,13]$ requires a lot of simulation time and is not readily suitable for fuel cell system integration purposes. The modeling approach used in this thesis involves relatively lesser number of equations to not compromise on simulation of the PEM fuel cell performance and was suitable for control purposes.

This thesis mainly concentrates on dynamically modeling the PEM fuel cell with stack temperature as a variable. To evaluate the grid integration characteristics of the PEM, it is vital to interface the PEM fuel cell with the electric utility grid using the Power Conditioning Unit (PCU). The PCU is made of several components such as the DC-DC booster, DC-AC inverter and transformers. Schematics and working evaluations of these components are available in almost all of the books on "Power Electronics". The book Power Electronics by Rashid, et.al, [14] was used as reference in this thesis. Mr. Robert Mills, currently employed as a Mechanical Engineer at Titan Systems, had the expertise in Power Electronics usage in the wind turbine industry. His expertise had also been used as a reference in designing the PCU for this thesis. 


\subsection{PEM Fuel Cell Control}

Controlling the PEM fuel cell output has been done in the literature using various approaches. Control of the PEM fuel cell often concentrates on a stand-alone PEM fuel cell. Certain control strategies try to control just the fuel flow rate relative to power demand. Control of PEM fuel cell in the grid-connected mode needs to satisfy more specifications. In this thesis, cascade control strategy was used to control the fuel flow rate and modulating amplitude to meet the desired voltage demand. 


\section{Chapter 4. Problem Statement and Approach}

\subsection{Various Issues dealt with in Thesis}

This chapter presents with the problem statement and approach for this thesis. Each of those issues are presented in this chapter.

1. Dynamic Modeling of a PEM Fuel Cell

2. Dynamic Modeling of the PCU

3. Integration of PEM Fuel Cell and the PCU to form the PEM Fuel Cell System

4. Design of two controllers:

a. Local Controller for the PCU

b. Global Controller for the PEM fuel cell system

\subsection{Dynamic Modeling of a PEM Fuel Cell with Variable Stack Temperature}

The Fuel cell stack temperature was considered to be a variable in this thesis. This dynamic condition affects the Nernst Equation and the component balance equation. The stack temperature has to be updated for each time step in calculating the output voltage using the Nernst Equation and component balance equation.

Changes in temperature were affected by the chemical reaction and also by heat transfer within cells. To calculate the changes in temperature with time, heat generated within cells and heat generated due to the chemical reaction were calculated.

For any given fuel flow rate, the PEM fuel cell can operate at different power levels 
depending on the line current. The total power generated, inclusive of the electric and thermal power generated, will be the same for a given fuel flow rate. When the electrical power generated decreases, the thermal power generated increases, subsequently increasing the stack temperature. The stack temperature of a fuel cell changes with changes in line current. The output voltage of a PEM fuel cell depends on temperature and line current. Hence, changes in line current will affect the stack temperature and the PEM fuel cell output voltage.

At the unit cell level, heat transfer occurs across the hydrogen, oxygen, electrode, electrolyte and bi-polar plate layers (See Figure 6.1). The hydrogen and oxidant gas layers conduct heat due to electro-chemical reaction. Convective heat transfer takes place between these layers. Conductive heat transfer occurs between electrode, electrolyte and bi-polar plate layer is the unit cell. Heat transfer starts from one end of a stack where the fuel manifold is located. Calculations are made to determine the stack temperature distribution across each layer and each cell based on the principles of thermodynamics and heat transfer.

The molar flow rate of input hydrogen and oxygen were calculated from component balance equation based on fuel flow rate and reaction rate. Nernst Equation was used for calculating the output fuel cell voltage. Ohmic, concentration and activation losses were incorporated with the Nernst Equation to calculate output voltage after losses.

\subsection{Modeling of PCU}

PCU modeling is necessary for integration of the PEM fuel cell system with the electric utility grid.

The PEM fuel cell output voltage had to be conditioned to 117 Volts, $60 \mathrm{~Hz}$, three-phase AC power, so that the PEM can be connected with the electric utility grid. The $45 \mathrm{~kW}$ PEM fuel 
cell used in illustrating this research had an output of 80-200 DC Volts. The required power transformation of this DC voltage was achieved using a Power Conditioning Unit (PCU) that consists of a DC-DC converter, inverter, line filters and transformers.

The PEM fuel cell connected to a PCU has to meet changes in the power demand by maintaining a constant output voltage. For small power demand changes $(<5 \%$ of PEM rated power), a control scheme was implemented by manipulating the inverter. For larger power demand changes ( $>5 \%$ of PEM rated power), a control scheme was implemented by manipulating the input fuel and oxidant flow rates.

For the power conversion process at various stages, each component of the PEM fuel cell system was represented as an object and its performance was simulated using MATLAB/Simulink.

\subsection{Design of Controllers}

\subsubsection{Local Controller for PCU}

For small duration of time during which power demand changes from the electric utility grid side occur, the PCU must be able to meet these demand changes. This was achieved by the varying the modulating amplitude of the PWM inside the inverter. A Proportional (P) control was implemented for this purpose.

\subsubsection{Global Controller for PEM Fuel Cell System}

For longer durations of time during which power demand changes from the electric utility grid side occur, simultaneously controlling of two variables, namely, fuel flow rate and air flow rate, enabled the demand changes to be met. 
Effective control of both variables was possible using cascade control. The fuel flow rate was considered as the master variable and modulating amplitude was considered as the slave variable. 


\section{Chapter 5. Dynamic Modeling of a PEM Fuel Cell}

\subsection{Introduction}

The fuel cell that was considered for this research was a $45 \mathrm{~kW}$ fuel cell with a voltage range of 80 to 200 Volts. The PEM fuel cell is a low temperature fuel cell. A lot of cells such as the unit cell shown in Figure 5.2 constitute a stack. For simplicity just one of the cells is shown. There is a chamber through which the fuel (hydrogen) is let in by means of a hydrogen control valve. Hydrogen comes in contact with a Platinum $(\mathrm{Pt})$ impregnated carbon electrode. Platinum, being a noble metal, serves as the catalyst.

The hydrogen atoms get separated as protons and electrons. The electrolyte is a solid, Sulphonated Poly Tetra Fluoro Ethylene (SPTFE) [21], which conducts just the positively charged hydrogen ions. The electrons travel through an external circuit to the cathode. Electrical work is done by the fuel cell. The hydrogen protons combine with the electrons from the cathode and oxygen atoms from another control valve.

\subsection{Dynamic Modeling Approach}

For any given fuel flow rate, the PEM fuel cell can operate at different power levels depending on the line current. The total power generated, inclusive of the electric and thermal power generated, will be the same for a given fuel flow rate. When the electrical power generated decreases, the thermal power generated increases, subsequently increasing the stack temperature distribution [11]. The stack temperature of a fuel cell changes with changes in line current. The output voltage of a PEM fuel cell depends on temperature and line current. Hence 
changes in line current will affect the stack temperature and the PEM fuel cell output voltage.

\subsection{Dynamic Modeling Assumptions}

Certain assumptions were made in developing a dynamic heat transfer model for the PEM fuel cell. These assumptions are all valid from an analytical modeling point of view. Listed below are those eight assumptions that were made during the modeling of the PEM fuel cell stack:

1. Gases involved behave ideally

2. Hydrogen is fully oxidized Homogenous temperature distribution across fuel gas, oxidant gas and electrolyte layers

3. Concentration of various species do not change

4. Co-flow conditions with fuel and oxidant gas

5. Temperature at the center of a unit cell layer is uniform through out that particular layer.

6. Heat transfer in gas passages is negligible.

7. Heat lost due to conduction and convection accounts for $20 \%$ of total heat generated.

8. Heat losses due to radiation are negligible.

\subsection{Stack Configuration Details}

A PEM fuel cell stack is comprised of several unit cells packed together in series. Each unit cell is made of several layers, which all together will be referred to as the cell cross sections in this thesis. The center of the unit cell is made of a polymer called SPTFE. This material has an affinity for protons and allows them to pass through its layer. SPTFE is sandwiched between 


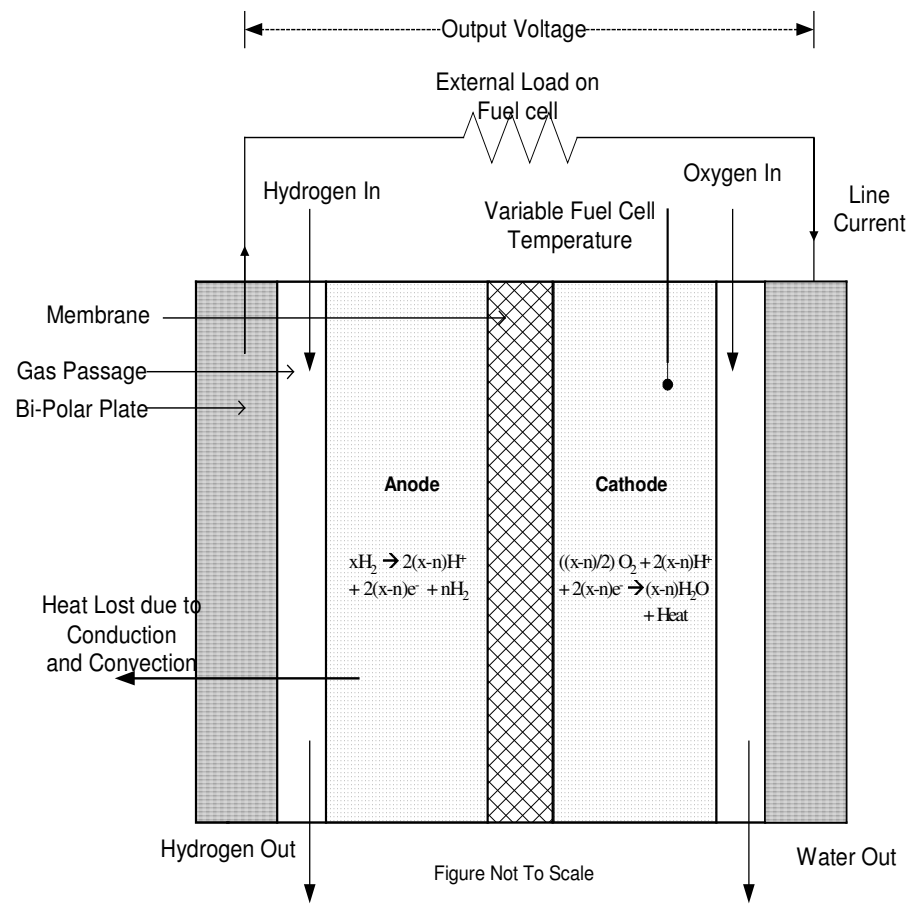

Figure 5.1: Cross-Sectional View of a Schematic PEM Unit Fuel Cell

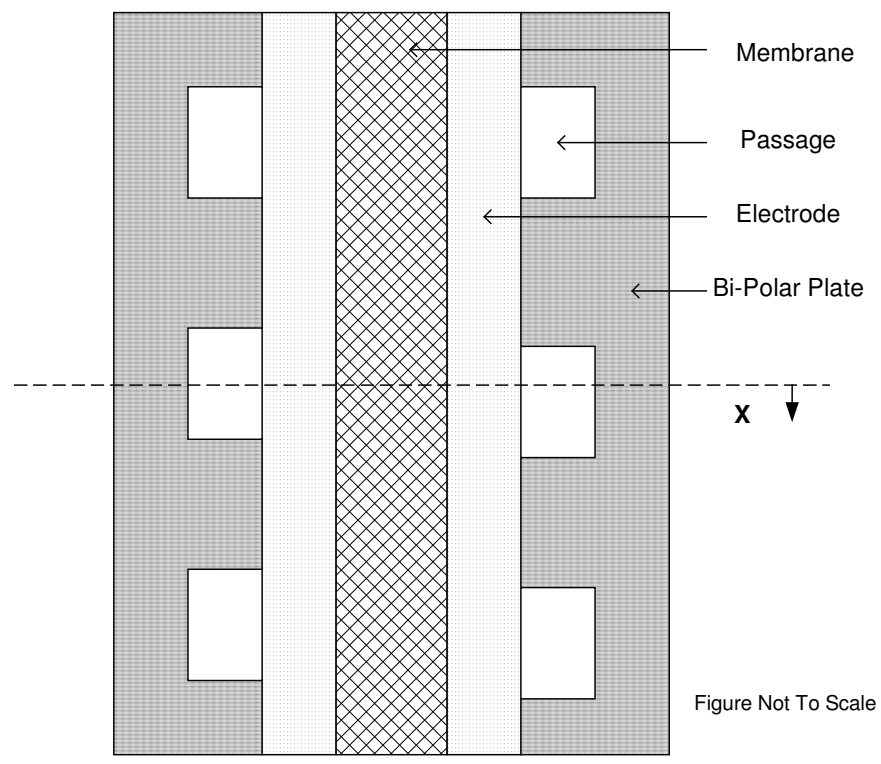

Figure 5.2: Top View of a Schematic PEM Unit Fuel Cell 
two electrode layers made of carbon paper. The electrode layers serve as the anode and cathode of the unit cell. Bi-polar plates sandwich the electrode layers. These bi-polar plates are made of graphite [16] and facilitate easy conduction of current between unit cells. The bi-polar plates have passages in between them to facilitate the flow of fuel and oxidant gases. All these layers together form a unit cell. Unit cells are then packed in series adjacent to each other. This forms a PEM fuel cell stack. The various details of the PEM fuel cell stack are shown in Table 5.1 and appropriate values from the Table were used in Equations.

Table 5.1: PEM Fuel Cell Stack Configuration Details

\begin{tabular}{|r|l|}
\hline Description & Detail \\
\hline Maximum Capacity & $45 \mathrm{~kW}$ \\
\hline Number of Cells in Series & 180 \\
\hline Cell Area & $0.05 \mathrm{~m} 2$ \\
\hline Bi-Polar Plate Thickness & $3 \mathrm{~mm}$ \\
\hline Electrode Thickness & $1.5 \mathrm{~mm}$ \\
\hline Membrane Thickness & $2 \mathrm{~mm}$ \\
\hline Channel Volume & $0.011 \mathrm{~m} 3$ \\
\hline Operating Temperature & $140-250^{\circ} \mathrm{F}$ \\
\hline
\end{tabular}

\subsection{Equations used in Modeling}

\subsubsection{Overall Chemical Reaction}

The three chemical reactions shown in Equations 5.1, 5.2 and 5.3 takes place inside a PEM fuel cell.

Anode Side Reaction:

$$
x H_{2}-\rightarrow 2(x-n) H++2(x-n) e^{-}+n H_{2}
$$

Cathode Side Reaction:

$$
((x-n) / 2) \mathrm{O} 2+2(x-n) H++2(x-n) e^{-} \rightarrow(x-n) H 2 O+\text { Heat }
$$

Overall Chemical Reaction: 


$$
\mathrm{xH} 2+((\mathrm{x}-\mathrm{n}) / 2) \mathrm{O} 2 \rightarrow(\mathrm{x}-\mathrm{n}) \mathrm{H} 2 \mathrm{O}+\mathrm{nH} 2
$$

On the anode side, hydrogen is separated into hydrogen protons and electrons, given by Equation 5.1. Electrons are conducted from the anode to the cathode by means of the bi-polar plates. Protons in the anode travel to the cathode through the proton absorbing SPTFE. These protons and electrons combine at the cathode with oxygen to produce water and heat, given by Equation 5.2. The $\mathrm{x}$ and $\mathrm{n}$ in these equations are the hydrogen flow in and out of a unit cell.

The stack temperature is considered to be a variable in this thesis. By doing so, one can predict the performance of a PEM fuel cell more accurately. Simulations for a longer period of time (more than 3600 secs) are possible when the stack temperature is a variable.

\subsubsection{Energy Balance Equation for a PEM Fuel Cell}

The energy balance equation for an open system PEM fuel cell as shown in Figure 5.1, using the First Law of Thermodynamics, can be expressed as

$$
\mathrm{M}_{s} \mathrm{C}_{s} \frac{d T_{s}}{d t}+\mathrm{M}_{s} \mathrm{~T}_{s} \frac{d C_{s}}{d t}=\mathrm{Q}_{\text {generated }}-\mathrm{Q}_{\text {losses }}
$$

Equation (5.4) [33] gives the energy balance equation for the PEM fuel cell. Here, $\mathrm{M}_{s}$ is the total mass of all the unit cells that comprise the fuel cell stack $(\mathrm{kg}), \mathrm{C}_{s}$ is the heat capacity of the stack $\left(\mathrm{kJ} / \mathrm{mol} .{ }^{\circ} \mathrm{F}\right), \mathrm{T}_{s}$ is the stack temperature $\left({ }^{\circ} \mathrm{F}\right), \mathrm{Q}_{\text {generated }}$ is the total heat generated in the fuel cell stack per unit volume $\left(\mathrm{kJ} / \mathrm{m}^{3}\right.$. sec), $\mathrm{Q}_{\text {losses }}$ is the heat lost due to conductive and convective heat transfer in the stack $\left(\mathrm{kJ} / \mathrm{m}^{3} . \mathrm{sec}\right)$. In Equation 5.4 values for change in heat capacity of the stack is not available. Hence, the temperature behavior given by Equation 5.4 was approximated to the real stack temperature curve shown in Reference 32.

\subsubsection{Component Balance Equation}

The component balance equation for the various components such as fuel, air and water 
is given in Equation 5.5 [23]. The amount of species inside the PEM at any instant is given by the difference in input and output specie flows, minus the species reaction rate.

$$
\frac{P V}{R T} \mathrm{~T}_{s} \frac{d x_{i}}{d t}=\mathrm{w}_{i}^{\text {in }}-\mathrm{w}_{i}^{\text {out }}-\mathrm{R}_{i}
$$

Where, $\mathrm{V}$ is the volume of the stack $\left(\mathrm{m}^{3}\right), x_{i}$ is the molarity of the species (no units), $\mathrm{w}_{i}{ }^{i n}$ is the inflow rate of the species (moles/sec), $\mathrm{w}_{i}{ }_{i}^{\text {out }}$ is the outflow rate of the species(moles/sec), $\mathrm{R}_{i}$ is the reaction rate (moles/sec) [24] of the species and $\mathrm{I}=1,2$ and 3 represents the species fuel, air and water, respectively

$$
\begin{aligned}
& \mathrm{R}_{H_{2}}=-\frac{I}{N F} \\
& \mathrm{R}_{H_{2}}=-\mathrm{R}_{H_{2} O}=2 \mathrm{R}_{O_{2}}
\end{aligned}
$$

where $\mathrm{R}_{\mathrm{H}_{2}}$ is the reaction rate of hydrogen (amps/Coulombs), I is the cell current (amps), $\mathrm{N}$ is the number of equivalents of chemical change, $\mathrm{F}$ is the Faraday's constant (Coulombs), $\mathbf{R}_{\mathrm{H}_{2} \mathrm{O}}$ is the reaction rate of water (amps/Coulombs) and $\mathrm{R}_{\mathrm{O}_{2}}$ is the reaction rate of oxygen (amps/Coulombs).

\subsubsection{Nernst Equation}

Equation 5.8 [24] gives the total output voltage E of the PEM fuel cell after ohmic, activation and polarization losses. Here, $\mathrm{E}$ is the total output PEM fuel cell voltage (Volts), $\mathrm{N}_{\text {cell }}$ is the number of cells in the PEM fuel cell stack (no units), $E^{\circ}$ is the standard electrode potential (Volts) and $\mathrm{E}_{\text {losses }}$ is the total voltage lost due to losses inside a PEM fuel cell (Volts). Assumption 1 to 3 holds good for Equation 5.8.

$$
\mathrm{E}=\mathrm{N}_{\text {cell }}\left(\mathrm{E}^{\circ}+\frac{R T_{s}}{4 F} \ln \frac{x_{H 2}{ }^{2} x_{O 2}}{x_{H 2 O}{ }^{2}}\right)-\mathrm{E}_{\text {losses }}
$$




\subsubsection{Total Heat Generated in a PEM Fuel Cell}

Total heat generated in a unit cell at any point in time is the difference between the total power generated in the ideal condition (condition where there are no losses in a PEM fuel cell), and the total real power generated at that point of time, which is given by Equation 5.9 [25]. $\mathrm{Q}_{\text {cell }}$ is the heat generated in a unit PEM fuel cell.

$$
\mathrm{Q}_{\text {cell }}=\mathrm{I}\left(\mathrm{E}^{\circ}-\mathrm{E}_{\text {cell }}\right)
$$

\subsubsection{Variation of Specific Heat for Ideal Gases with Changes in Temperature}

Equation 5.10 [27] gives the variation of specific heat for ideal gases with changes in T, which is the temperature of the specie gases $\left({ }^{\circ} F\right)$.

$$
\frac{c_{p}}{R}=\alpha+\beta T+\gamma T^{2}+\delta T^{3}+\varepsilon T^{4}
$$

where $\mathrm{R}$ is the universal gas constant $\left(\mathrm{mol}^{-10} \mathrm{~F}^{-1}\right)$ generated per unit cell $\left(\mathrm{kJ} / \mathrm{m}^{3}\right.$. sec) and $\mathrm{V}_{\text {cell }}$ is the voltage of a unit cell (Volts).

\subsubsection{Cross Section Temperature and Heat Generated Relationship}

Equation 5.11 was developed using the concepts of thermodynamics and heat transfer, and gives the relationship between temperature at various cross sections and the total heat generated in a unit cell.

$$
\mathrm{Q}_{\text {cell }}=\frac{\alpha\left(T_{\left(N_{\text {cell }}, \text { initial }\right)}-T_{\left(N_{\text {cell }}, \text { final }\right)}\right)}{2\left(\frac{L_{e}}{k_{e} A_{e}}+\frac{L_{b}}{k_{b} A_{b}}\right)+\frac{L_{m}}{k_{m} A_{m}}+\frac{1}{h_{a} A_{a}}+\frac{1}{h_{c} A_{c}}}
$$

Here, $\alpha$ is the heat correction factor (no units), $\mathrm{T}_{\left(N_{\text {cel }}, \text { initial }\right)}$ is the initial temperature of the cross section in the direction of heat flow $\left({ }^{\circ} \mathrm{F}\right),\left(\mathrm{T}_{\left(N_{\text {cell }}, \text { final }\right)}\right.$ is the final temperature of cross section in the direction of heat flow $\left({ }^{\circ} F\right), \mathrm{L}_{b}$ is the length of bi-polar plate $(\mathrm{m}), \mathrm{L}_{e}$ is the length of 
electrode $(\mathrm{m}), \mathrm{L}_{m}$ is the length of membrane $(\mathrm{m}), \mathrm{k}_{e}$ is thermal conductivity of electrode $(\mathrm{kJ} / \mathrm{m}$. $\left.{ }^{\circ} \mathrm{F}\right), \mathrm{k}_{b}$ is the thermal conductivity of bi-polar plate $\left(\mathrm{kJ} / \mathrm{m} .{ }^{\circ} \mathrm{F}\right), \mathrm{k}_{m}$ is the thermal conductivity of membrane $\left(\mathrm{kJ} / \mathrm{m} .{ }^{\circ} \mathrm{F}\right), \mathrm{A}_{e}$ is the cross sectional area of electrode $\left(\mathrm{m}^{2}\right), \mathrm{A}_{b}$ is the cross sectional area of bi-polar plate $\left(\mathrm{m}^{2}\right), \mathrm{A}_{m}$ is the cross sectional area of membrane $\left(\mathrm{m}^{2}\right), \mathrm{A}_{a}$ is the cross sectional area of the anode $\left(\mathrm{m}^{2}\right), \mathrm{A}_{c}$ is the cross sectional area of the cathode $\left(\mathrm{m}^{2}\right), \mathrm{h}_{a}$ is the convective co-efficient of anode gas $(\mathrm{kJ} / \mathrm{kg})$ and $\mathrm{h}_{c}$ is the convective coefficient of the cathode gas $(\mathrm{kJ} / \mathrm{kg})$ Heat correction factor was calculated using the temperature distribution curve shown in Reference 34. Assumptions 4 to 8 hold good for Equation 5.11.

\subsubsection{Total Heat Generated and Cell Heat Relationship}

The total heat generated in a PEM fuel cell stack given by Equation 5.12 and is the sum of all heats generated at each unit cell. Here, $\mathrm{Q}_{\text {cell }}$ is the heat generated per unit cell $\left(\mathrm{kJ} / \mathrm{m}^{3}\right.$. sec).

$$
\mathrm{Q}_{\text {generated }}=\sum Q_{\text {cell }}
$$

\subsection{PEM Fuel Cell Model}

\subsubsection{PEM Fuel Cell Non-linear Model}

PEM fuel cell non-linear model was developed as shown in Appendix A and Appendix B using MATLAB/Simulink. Equations 5.4 to 5.12 were the main equations used in developing the non-linear model in Simulink and primarily accounts for PEM fuel cell behavior as shown in Figures 9.1 and 9.5

\subsubsection{PEM Fuel Cell Linear Model}

\subsubsection{Introduction}


Input for a PEM fuel cell model is hydrogen flow rate and it outputs DC voltage. Other inputs, such as, oxygen flow rate and exit water flow rate are proportional to the flow rate of hydrogen. Oxygen flow rate is equal to half of hydrogen flow rate. Exit water flow rate is equal to hydrogen flow rate.

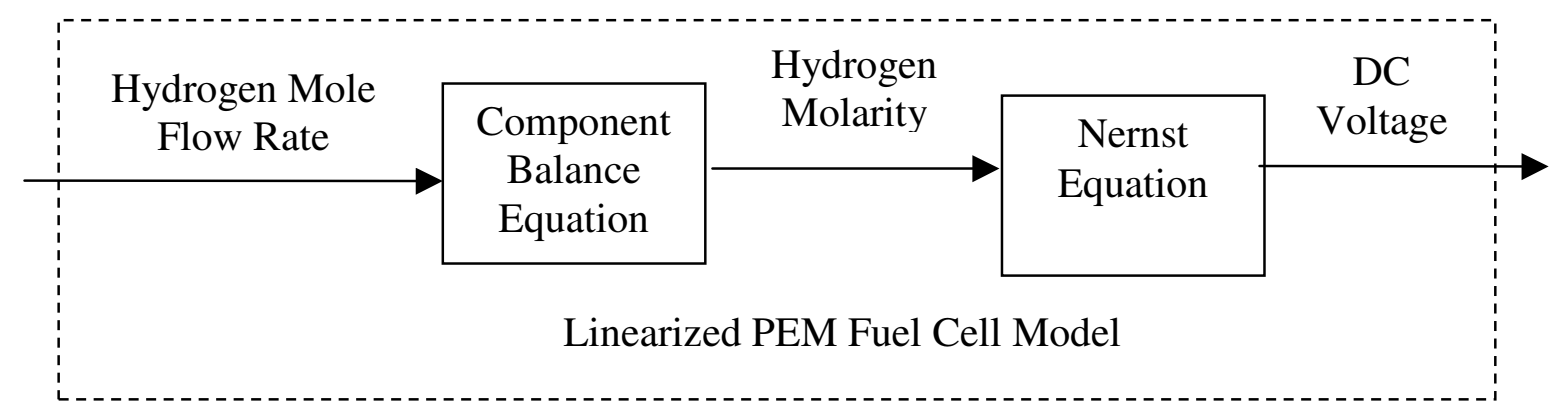

Figure 5.3: Linearized PEM Fuel Cell Model Block Diagram

The linearized PEM fuel cell model holds good within the operating conditions tabulated in Table 5.2. Input hydrogen flow rate is a variable (2.5 to 5 moles $/ \mathrm{sec})$

Table 5.2: Operating Conditions for Linearized PEM Fuel Cell Model

\begin{tabular}{|c|c|}
\hline Fuel Cell Parameters & Assumed Constants \\
\hline Line Current & $200 \mathrm{amps}$ \\
\hline Voltage & $80-88$ Volts \\
\hline Temperature & $176^{\circ} \mathrm{F}$ \\
\hline Pressure & $17.4 \mathrm{psi}$ \\
\hline
\end{tabular}

\subsubsection{Hydrogen Component Balance Transfer Function}

Outflow rate of hydrogen is proportional to the molarity or mole fraction of hydrogen. By trial and error, this value was calculated as $0.02(1 / \mathrm{sec})$. This is expressed as shown in Equation 5.13.

$$
N_{H 2}^{\text {out }}=0.02 x_{H 2}(\text { moles } / \mathrm{sec})
$$


Using Equation 5.5, Equation 5.6, Equation 5.13 and Table 5.2, hydrogen component balance equation is derived as shown in Equation 5.14.

$$
0.45 \frac{d x_{H 2}}{d t}+0.02 x_{H 2}+1.036 \times 10^{-3}=N_{H 2}^{i n}
$$

Taking Laplace on both sides of Equation 5.14 yields hydrogen component balance transfer function $G_{H C B}(s)$ as shown in Equation 5.15.

$$
G_{H C B}(s)=\frac{x_{H 2}(s)}{N_{H 2}^{i n}(s)}=\frac{1}{0.45 s+0.02}(\mathrm{sec} / \mathrm{mole})
$$

\subsubsection{Voltage Transfer Function}

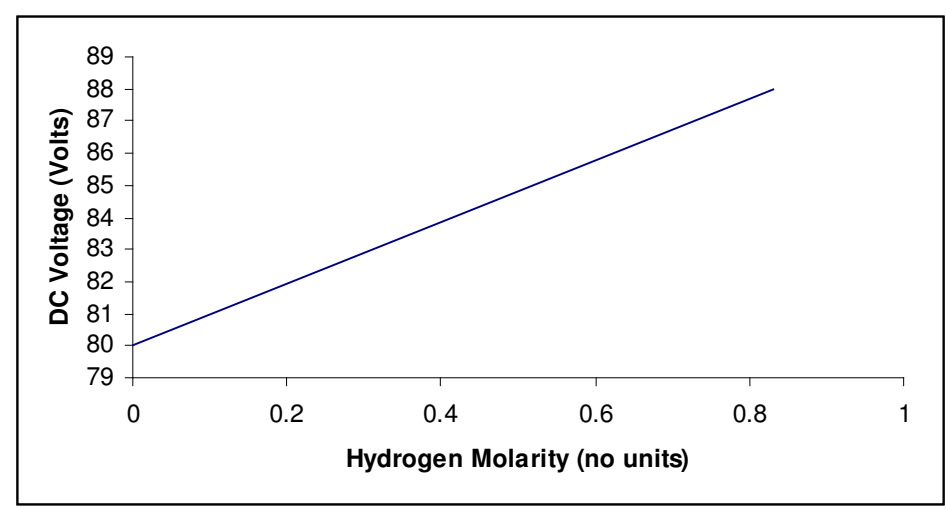

Figure 5.4: PEM Fuel Cell Output Under Specified Operating Conditions

Figure 5.4 shows the PEM fuel cell output calculated using Equation 5.8 under operating conditions specified in Table 5.2. Equation for the line in Figure 5.4 yields the relation as shown in Equation 5.16.

$$
\mathrm{E}=9.6 x_{\mathrm{H}_{2}}+80
$$

Taking Laplace on both sides of Equation 5.17 lead to developing Voltage transfer function as, 


$$
G_{V}(s)=\frac{E(s)}{x_{H 2}(s)}=9.6 \text { (Volts) }
$$

\subsubsection{PEM Fuel Cell Transfer Function}

PEM fuel cell transfer function $G_{P E M}(s)$ was developed by multiplying hydrogen component balance transfer function and voltage transfer function as shown in Equation 5.18.

$$
G_{P E M}(s)=G_{H C B}(s) \cdot G_{V}(s)
$$

Substituting Equation 5.16 and Equation 5.18 yields Equation 5.19.

$$
\frac{E(s)}{N_{H 2}^{\text {in }}(s)}=\frac{9.6}{0.45 s+0.02}\left(\frac{\text { Volts.sec }}{\text { moles }}\right)
$$




\section{Chapter 6. Power Conditioning Unit for PEM Fuel Cell}

\subsection{Introduction}

Assume a PEM Fuel Cell outputs 80 Volts DC. To interface the fuel cell to an electric utility load there are certain conditions for synchronization. Four conditions for synchronization are as follows:

1. The output voltage from the fuel cell side should be three phase AC Voltage.

2. Each phase should be 117 Volts RMS and 165 Volts Peak.

3. The phase voltages should have a lag of $120^{\circ}$ from one another.

4. The frequency of output sinusoidal voltage should be $60 \mathrm{~Hz}$.

A Power Conditioning Unit (PCU) was designed so that it converts the output voltage from the fuel cell to be suitable for synchronization with electric utility grid. The Power Conditioning Unit used in this thesis primarily consists of a DC-AC inverter.

\subsection{DC-AC Inverter}

Inverter is a power electronics device that converts DC Voltage into AC voltage at a desired magnitude and desired frequency [28]. Input for an inverter was DC Voltage and the output AC voltage depends on the input, magnitude of carrier wave and magnitude of a sine wave in the case of a Pulse Width Modulation (PWM) controlled sinusoidal inverter. Inverters can be broadly classified into two types:

1. Step down inverters

2. Step up inverters 
A step down inverter converts higher input DC voltages into lower AC voltages. Step up inverters convert lower input DC voltages into higher AC voltages. Input DC voltage from the PEM fuel cell was in the range of 80-88 Volts and the required output AC Voltage was 117 Volts. In this thesis a step up inverter can serve the purpose of fuel cell interfacing PEM fuel cell with the load.

A PWM controlled sinusoidal step up inverter was designed [29] in Simulink as shown in Figure C.3. MOSFETs 1 to 6 represent the switches inside the inverter. There are three phases [R (Red), Y (Yellow), B (Blue)] and a neutral phase N. For each phase there is one set of carrier wave generator, sine generator and two diodes.

First, a working description is provided for the R-Phase. Carrier-R Phase was a triangular wave with positive peak magnitude of 10 and negative peak magnitude of -10 . In this thesis the magnitudes of the carrier wave was maintained a constant. The frequency of the triangular wave was $500 \mathrm{~Hz}$. Modulating wave-R Phase is a sinusoidal wave with variable magnitude and frequency. Magnitude of the modulating wave is changed to control the magnitude of the output AC voltage.

MOSFETs 1, 3 and 5 are called the upper leg switches. MOSFETs 2, 4 and 6 are called their complementary switches, respectively. Whenever the magnitude of the carrier wave was greater than the magnitude of the modulating wave, upper leg switch MOSFET1 turns on and allows the input DC voltage to flow through it. At that instant of time when MOSFET1 was on, its complementary MOSFET2 will be off and vice versa. Based on this switching sequence, instantaneous sinusoidal voltage $\mathrm{Vr}$ is generated. In the same manner as described above, other two instantaneous voltages $\mathrm{Vb}$ and $\mathrm{Vy}$ are generated.

$$
\text { Vry }=\text { Vr-Vy }
$$




$$
\begin{aligned}
& \mathrm{Vyb}=\mathrm{Vy}-\mathrm{Vb} \\
& \mathrm{Vbr}=\mathrm{Vb}-\mathrm{Vr}
\end{aligned}
$$

Equation 6.1, Equation 6.2 and Equation 6.3 gives the relation between the line voltages Vry, Vyb, Vbr and the instantaneous voltages. Equation 6.4, Equation 6.5 and Equation 6.6 gives the relation between the phase voltages Vrn, vyn, Vrn and the line voltages.

$$
\begin{aligned}
& \mathrm{Vrn}=\frac{V r y-V b r}{3} \\
& \mathrm{Vyn}=\frac{V y b-V r y}{3} \\
& \operatorname{Vrn}=\frac{V b r-V y b}{3}
\end{aligned}
$$

Equation 6.7, based on established concepts of Power Electronics, gives the relation between phase voltage, input DC voltage, magnitude of the modulating wave and the carrier wave. $\mathrm{M}_{a}$ will be referred to as the inverter gain from now on in this thesis.

$$
\mathrm{Vrn}=0.45 \mathrm{~V}_{D C} \frac{M_{a}}{M_{c}}
$$

Simulink diagrams for the calculations of line and phase voltages are shown in Appendix C. Result for the PCU is shown in Figure 9.11. 


\section{Chapter 7. PEM Fuel Cell Control System}

\subsection{Introduction}

The PEM fuel cell is a MIMO system. A Cascade control strategy (Master-Slave control) was used to control operation of the PEM fuel cell. The fuel flow rate was chosen as the master variable (primary) and inverter gain was chosen as the slave variable (secondary). According to the design criteria [18] for cascade control, the slave variable dynamics should be faster (at least three time faster) than that of the master variable dynamics. It was found in the literature that the dynamics of the inverter in a PEM are much faster than the dynamics of the fuel flow rate.

\subsection{Cascade Control for PEM Fuel Cell}

Figure 8.1 shows the Simulink diagram of Cascade Control for PEM fuel cell. This scheme uses a linearised fuel cell transfer function from the results obtained from the nonlinear fuel cell model developed in Chapter 5.

The desired fuel cell DC voltage was converted into the corresponding command current signal Id by the converter. The current signal from the sensor Ia, which was basically the feedback signal, was compared with Id and the error is used as the input for the master controller. The output from the master controller was used as the input for the flow valve.

The input for the linearised fuel cell model was the fuel flow rate and output was DC voltage. This output DC voltage and desired AC voltage was multiplied by the secondary controller gain. 


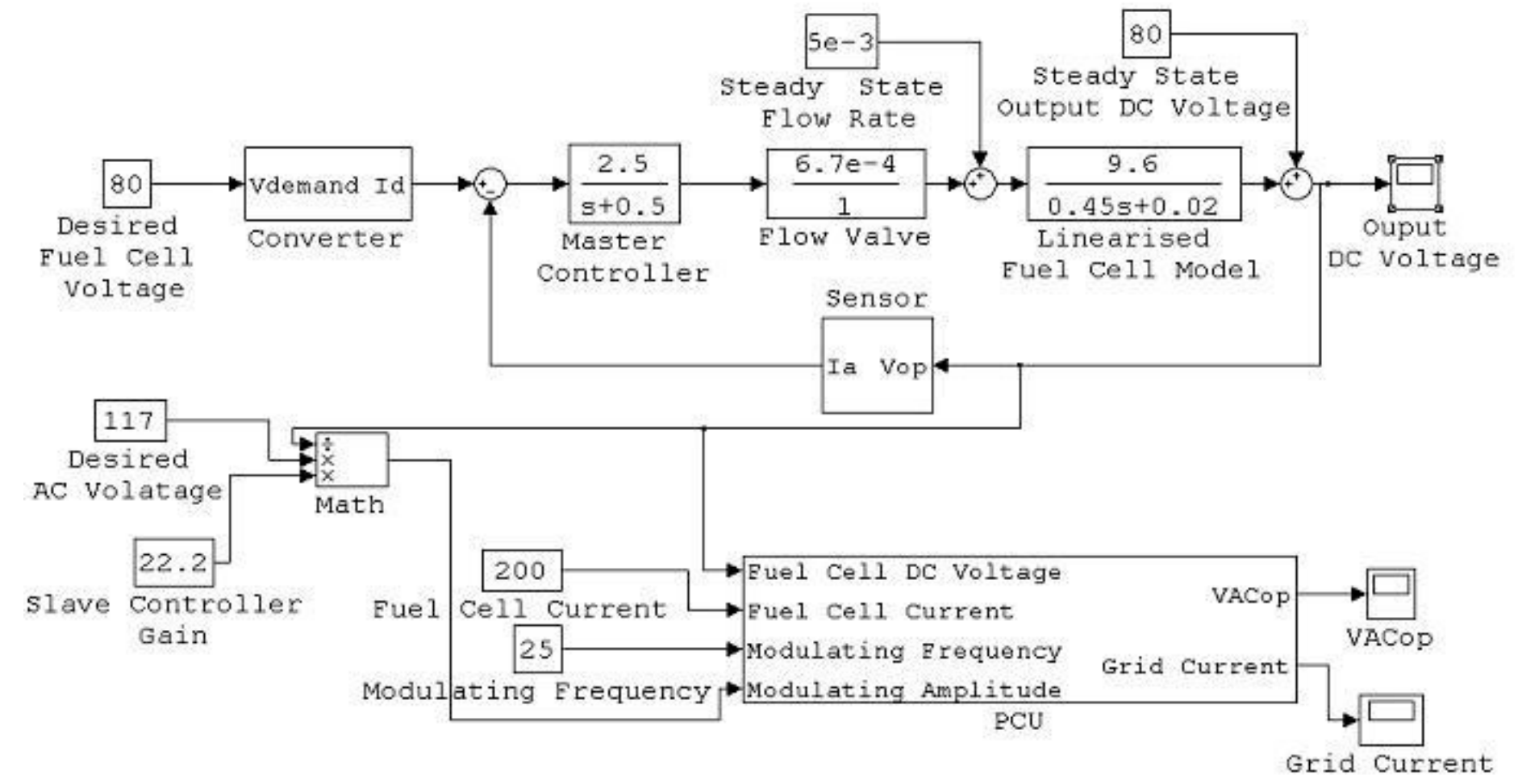

Figure 7.1: Simulink Diagram for PEM Fuel Cell System Control 
Controller output was the magnitude of the modulating wave of the PWM associated with the PCU. The PCU has been described in Chapter 6. Based on fuel cell DC voltage, fuel cell current, modulating frequency and slave controller output, the PCU outputs the desired three phase AC voltage.

\subsection{Master Controller for PI Control of Fuel Flow Rate in PEM Fuel Cell}

Equation 8.1 gives the transfer function for the primary controller.

$$
\frac{I_{F}}{I e}=\frac{2.5}{s+0.5} \text { (no units) }
$$

For the fuel cell output DC voltage response without the controller (discussed in Chapter 8), the rise time was found to be quite high. The fuel cell performance was improved by decreasing the rise

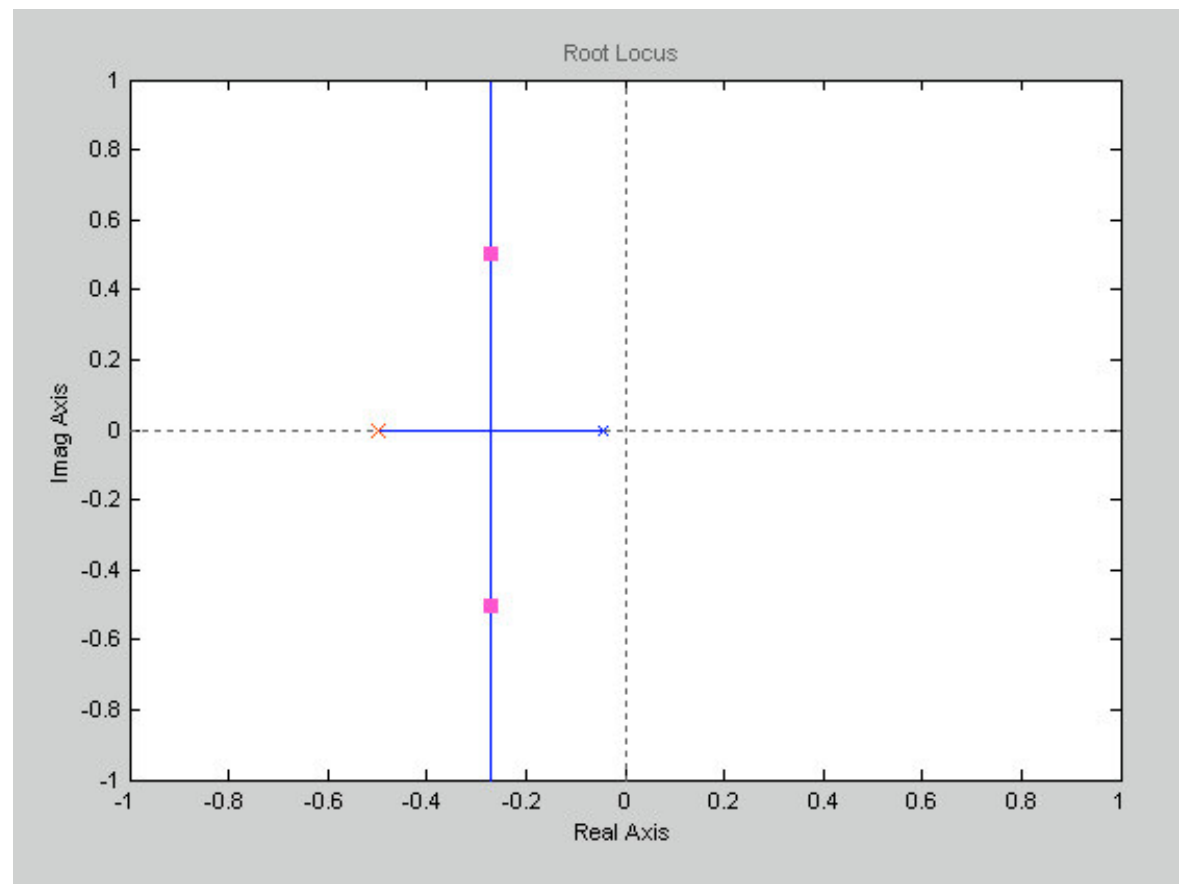

Figure 7.2: Root locus for PEM Fuel Cell

time. To achieve a decrease in rise time, an integral gain was introduced in trial and error study. the master controller. To decrease the settling time of the output DC voltage a proportional gain was 
introduced in the master controller. Thus a Proportional-Integral (PI) controller was used as the master controller. Values for P and I terms shown in Equation 8.1 were selected by trial and error.

The master controller was tested for stability using the SISO tool function available in MATLAB. Figure 7.2 shows the root locus diagram for the closed loop PEM fuel cell system. Both the pole and zero lie in the left hand plane of the root locus. Figure 7.3 shows an open loop Bode diagram. The gain margin was found to be infinity and phase margin is 146 degrees. This is well above the stability constraints. The PEM fuel cell system was found to be stable within the operating conditions using the designed PI controller.

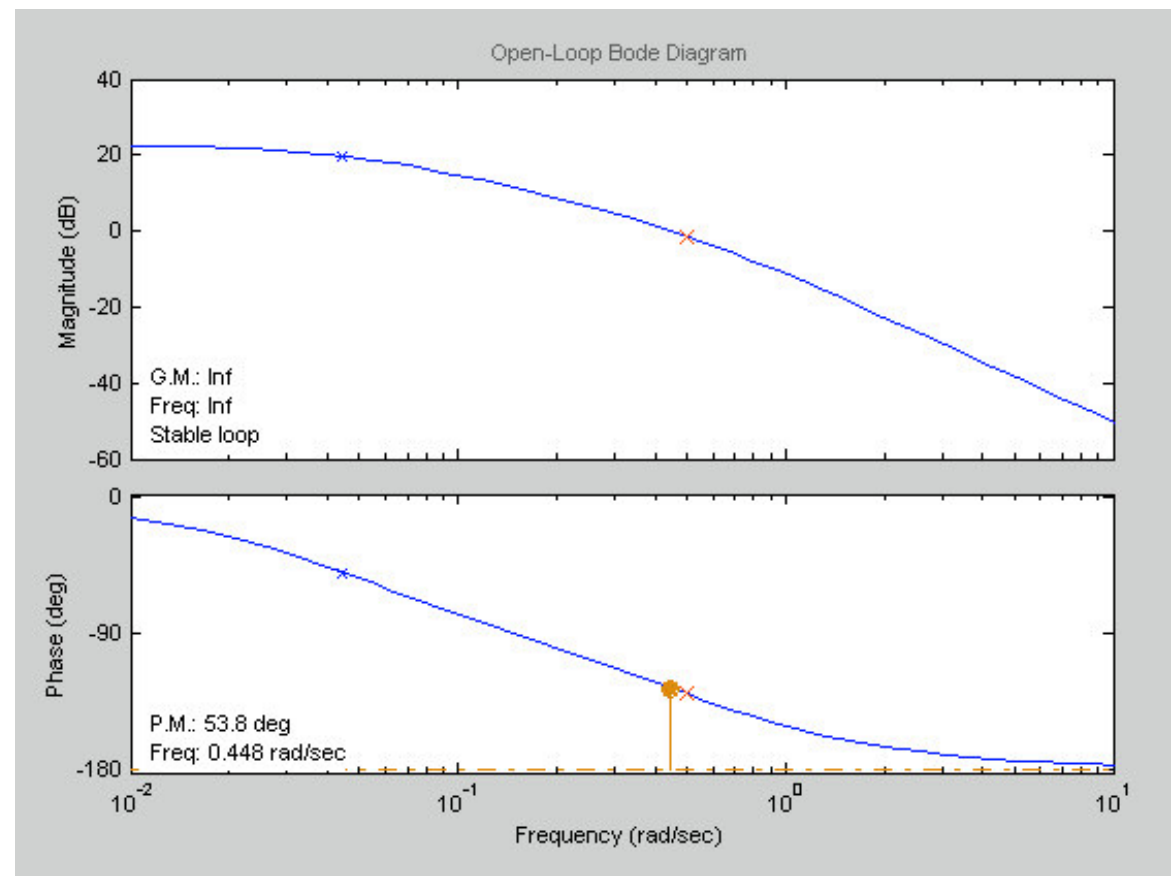

Figure 7.3: Bode Plot for PEM Fuel Cell 


\subsection{Slave Controller for P Control of Modulating Amplitude of PCU}

As discussed in Chapter 6, the magnitude of the carrier wave was maintained as a constant at 10. Thus, the slave controller was calculated as designed as shown in Equation 7.3.

$$
\mathrm{G}_{c}(s)=22.2 \text { (no units) }
$$




\section{Chapter 8. Results and Discussion}

\subsection{PEM Fuel Cell Characteristics}

A model for a PEM fuel cell was developed with minimum process variables and without compromising the fuel cell behavior.

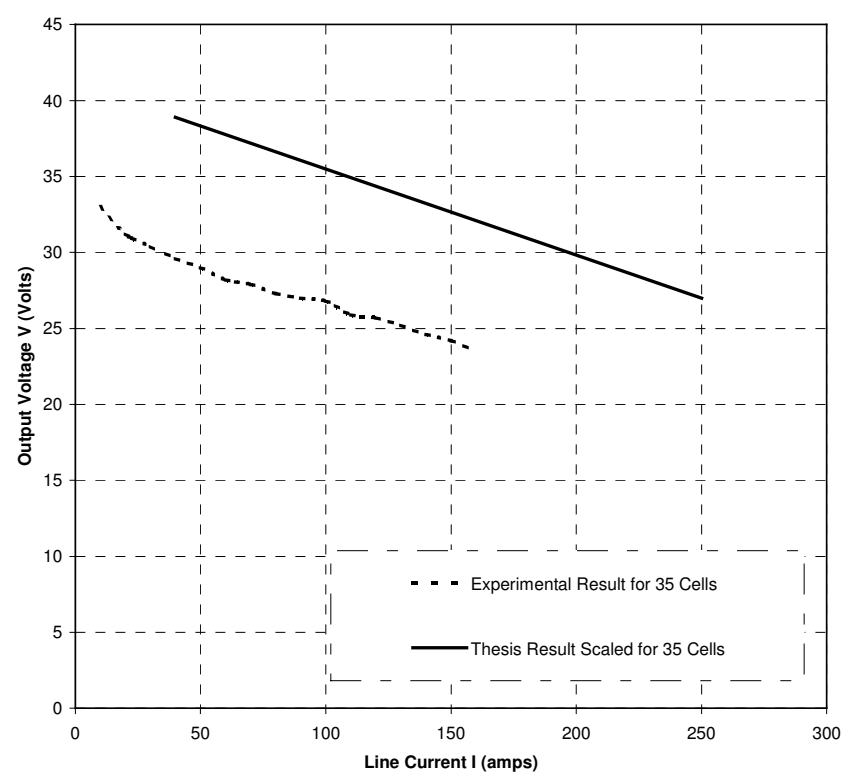

Figure 8.1: PEM Output Voltage Vs Line Current

Fuel cell output voltage was plotted with changes in line current for a fuel flow rate of $0.0043 \mathrm{gms} / \mathrm{sec}$. To make sure that the model works good, above Thesis result was compared with the experimental result [31] available for 35 PEM unit cells. This Thesis result was then simulated for 35 cells in order to compare as shown in Figure 8.1 and the trend nearly matched the Thesis model results. Under the same conditions, fuel cell output power was plotted respect to with line current. Simulation results are shown in Figure 8.1 and Figure 8.2. Fuel cell voltage decreases with increase in line current. 


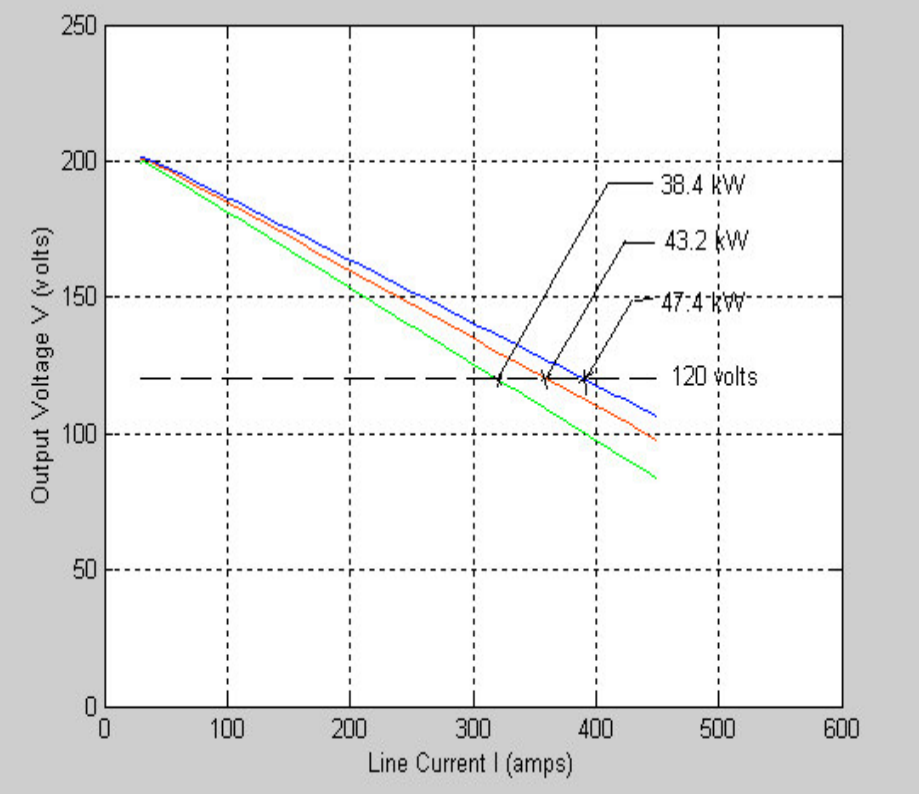

Hydrogen flow rate:

$0.0050 \mathrm{gm} / \mathrm{sec}$

$0.0043 \mathrm{gm} / \mathrm{sec}$

$0.0030 \mathrm{gm} / \mathrm{sec}$

Continuous operating conditions:

- Variable stack temperature: $170-188^{\circ} \mathrm{F}$

- Stack power output: $35-50 \mathrm{~kW}$

Figure 8.2: PEM Output Voltage Vs Line Current with Various Power Levels

Figure 8.3 shows the output power characteristics for the PEM fuel cell. Output power increases steadily with line current up to 320 Amps. After 320 Amps, the output power does not increase any further with increase in current. One can see that the output power reaches the maximum design capacity and becomes stagnated at $45 \mathrm{~kW}$. The V-I and Power curve trends for this fuel cell model look similar to various other simulation results [30]. These results are also comparable with the results from Reference 31 .

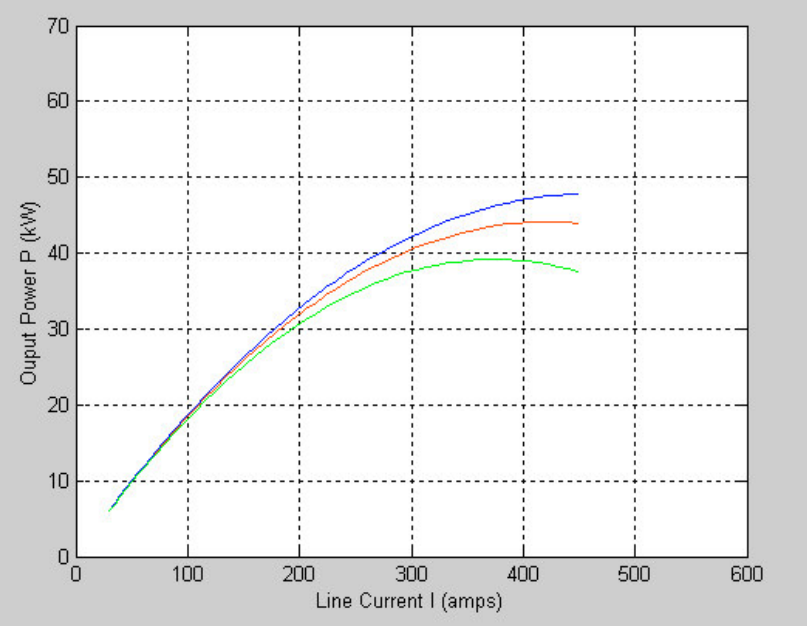

Figure 8.3: PEM Output Power Vs Line Current 


\subsection{Temperature Dynamics for the PEM Fuel Cell}

Previous works on fuel cells had assumed stack temperature to be a constant. This research pursued allowing the stack temperature for the PEM fuel cell to change. The PEM fuel cell behavior thus was modeled more accurately, with changes in stack temperature included. Thus, the performance of the PEM fuel cell was enhanced accordingly.

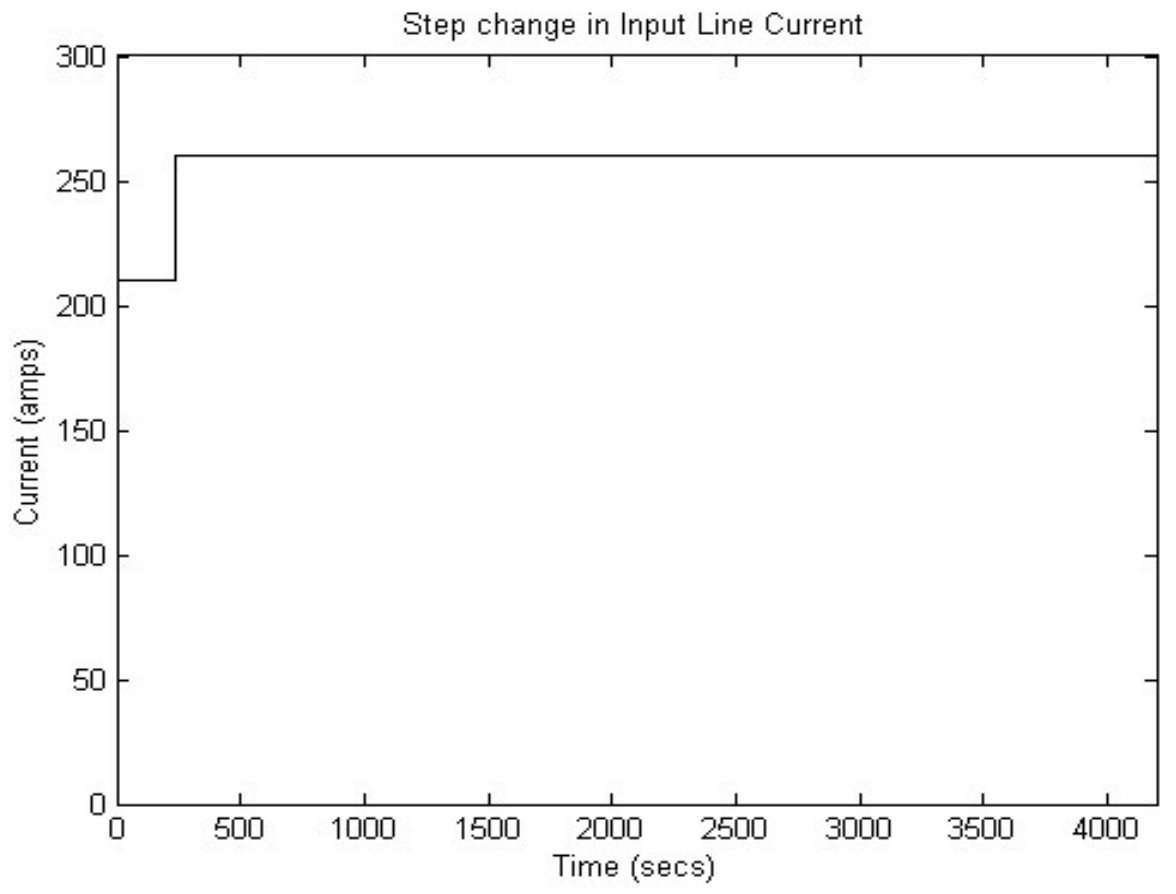

Figure 8.4: Step Change in Input Line Current Vs Time

The line current of the PEM fuel cell was changed by 50 amps from 210 amps to 260 amps, as shown in Figure 8.4. This step change takes place when the time was 215 secs. The entire simulation took place over a period of 4200 secs.

Line current serves as the input to the PEM fuel cell model. During this simulation, the input fuel and oxidant flow rates were kept constant. This increase in line current decreases the voltage and eventually the fuel cell output power. As discussed earlier in Chapter 5, a decrease in the real power caused an increase in heat generated inside the stack and an increase in stack temperature distribution across stack cross sections. 


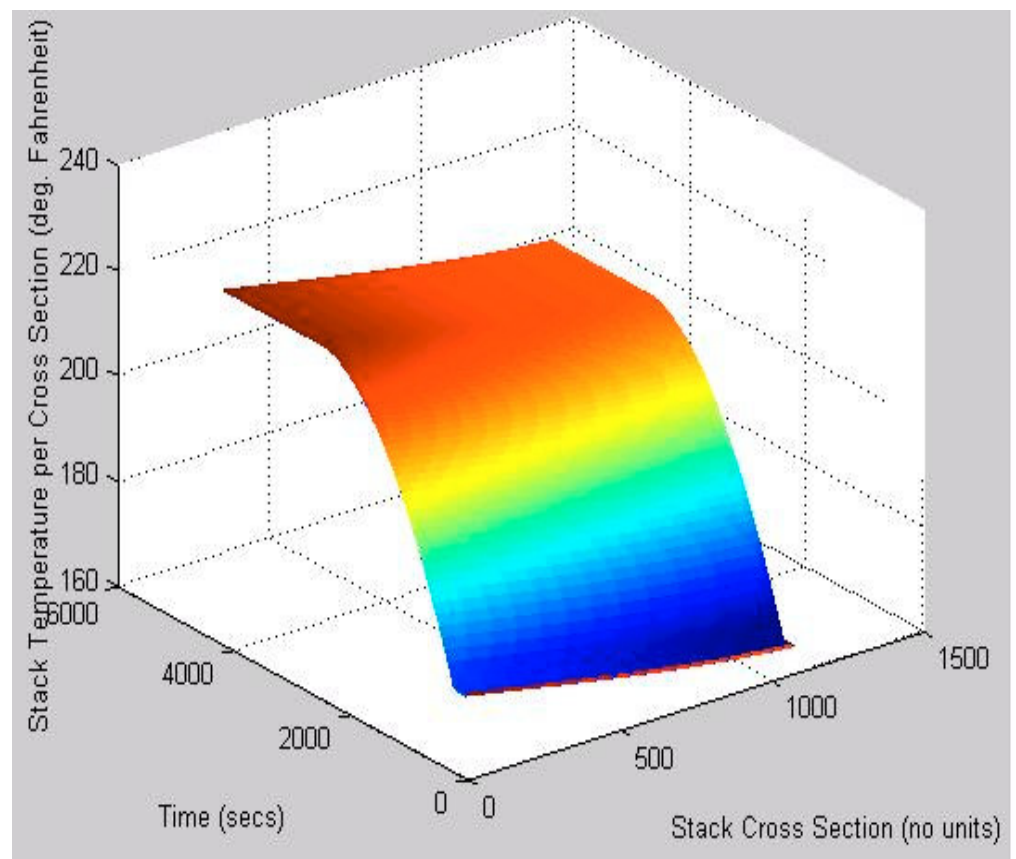

Figure 8.5: Stack Temperature Distribution Across Stack Cross Sections Over a Time Period of 4200 secs.

The stack temperature distribution across stack cross sections over a time period of 4200 secs was shown in Figure 8.5. This stack temperature distribution simulated the same stack temperature distribution shown by Wei He [34] on a one-dimensional macromodeling platform

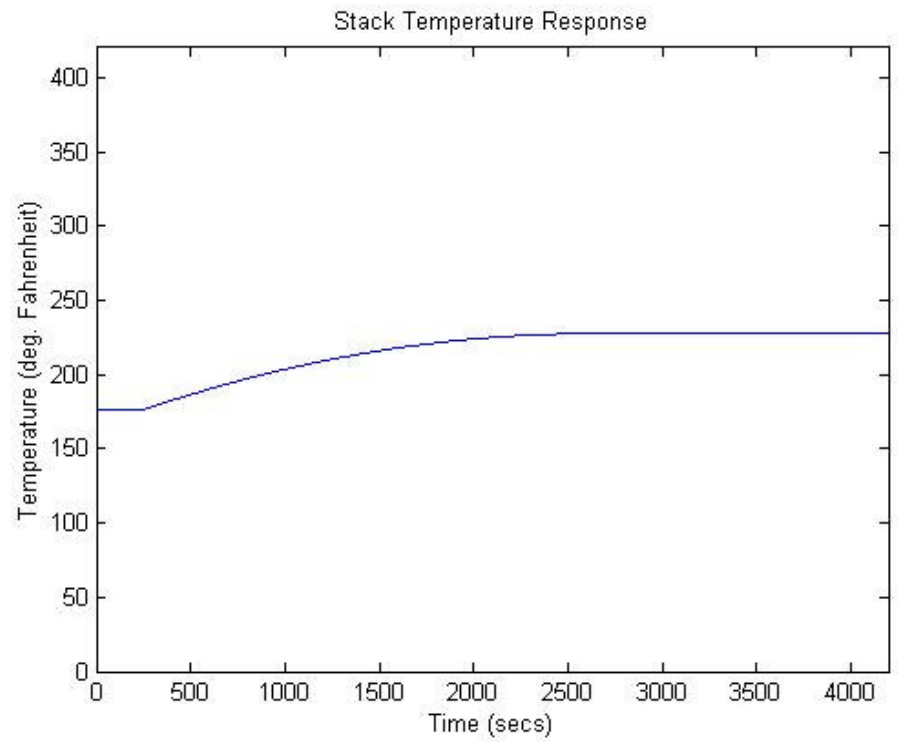

Figure 8.6: Stack Temperature Response due to Change in Input Line Current using analytical equations and MATLAB/Simulink. 


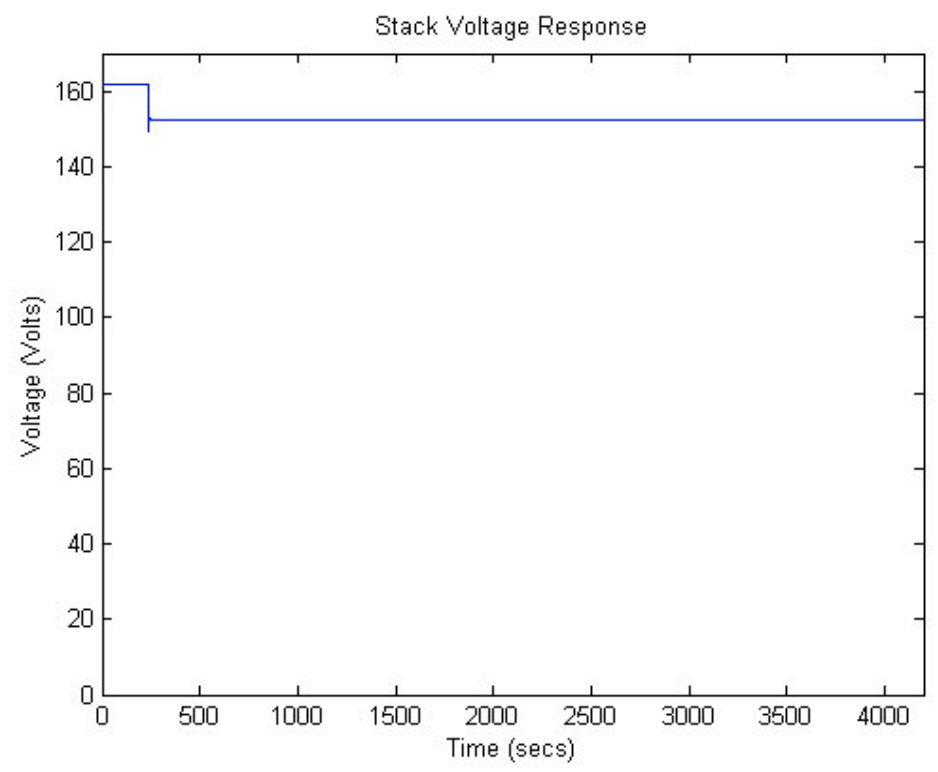

Figure 8.7: Stack Output Voltage Response due to Change in Input Line Current and Stack Temperature

The stack temperature at any point of time was calculated by averaging the stack temperature distribution across stack cross sections at the same point of time. This attributes to the stack temperature response shown in Figure 8.6. Stack temperature rised from $170{ }^{\circ} \mathrm{F}$ to 228 ${ }^{\circ} \mathrm{F}$ over a period of $1700 \mathrm{secs}$, at the rate of $0.03{ }^{\circ} \mathrm{F} / \mathrm{min}$. During the same period of time when

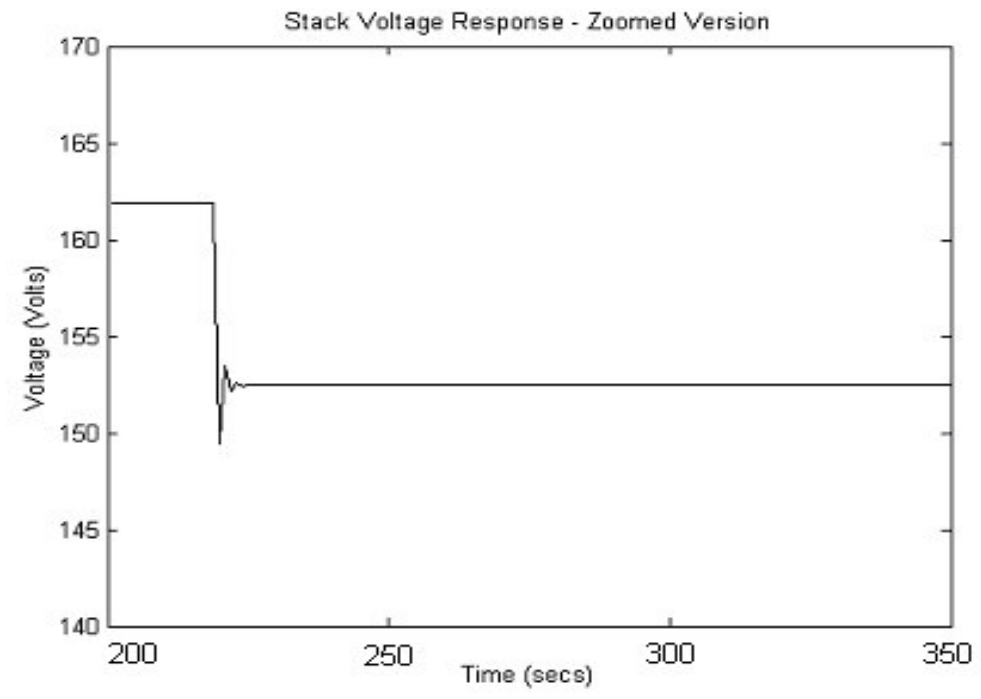

Figure 8.8: Stack Output Voltage Response During 200-350 secs due to Change in Line Current and Stack Temperature 
line current was step changed, output voltage had decreased by 9.5 Volts. Figure 8.7 shows output voltage of the PEM fuel cell due to the step change in input line current. The voltage decreases from 162 Volts to 153 Volts, at 240 seconds. This study was conducted assuming the surrounding temperature was under ambient conditions.

Figure 8.8 shows the enlarged version of the output voltage from 200 seconds to 350 seconds. When the voltage decreased, it first jumped to 149 Volts and settled down over a period of 10 secs. The obtained results simulated the experimental behavior of a $5 \mathrm{~kW}$ Ballard PEM fuel cell stack [32], for a larger stack - the $45 \mathrm{~kW}$ PEM fuel cell stack, on a onedimensional macromodeling platform using analytical equations and MATLAB/Simulink.. For a 50 amp step change in current, the stack temperature of the Ballard fuel cell rised at the rate of $0.03{ }^{\circ} \mathrm{F} / \mathrm{min}$ and the voltage decreased by 1 Volt. Thesis results are also comparable with Reference 35 .

\subsection{Linear PEM Fuel Cell System Model Control Results}

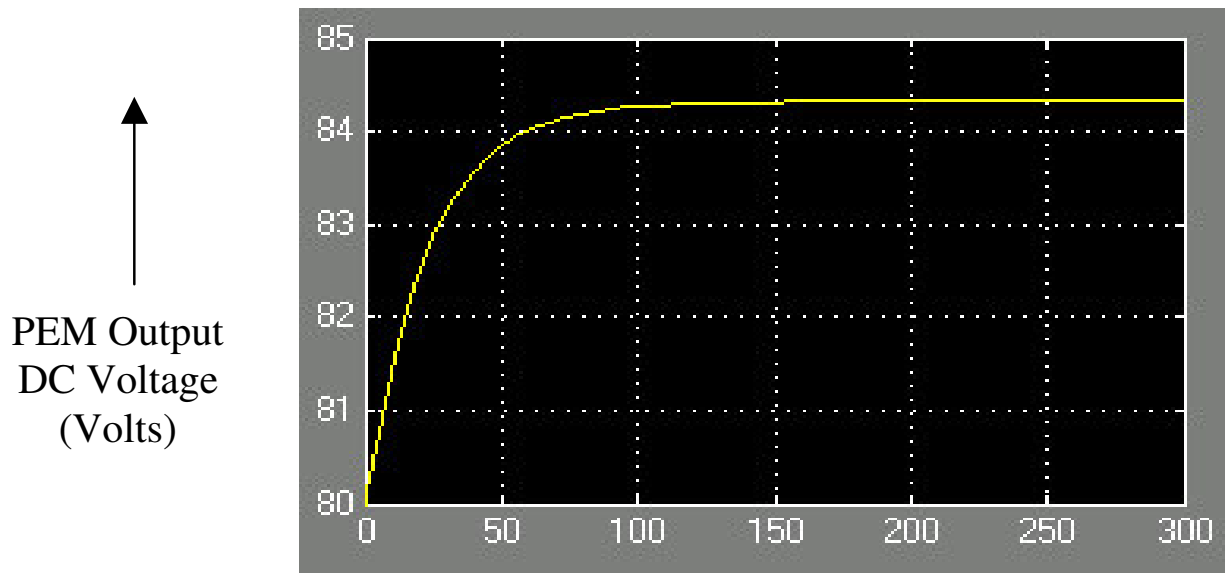

Time (secs)

Figure 8.9: PEM Output DC Voltage Response without Controller 
Figure 8.9 shows the output DC voltage response of the PEM fuel cell system and the rise time was found to be 150 secs. Figure 8.10 shows the output DC voltage response of the PEM inclusive of the PI controller. Fuel cell performance has improvised with a controller - rise time was enhanced by 125 secs and the settling time was found to be 5 secs. Figure 8.11 shows the three phase AC output voltage of the PCU and the peak voltage were found to be 165 Volts (equivalent to 117 Volts RMS). Figure 8.11 shows the output three phase AC voltage from the PCU.

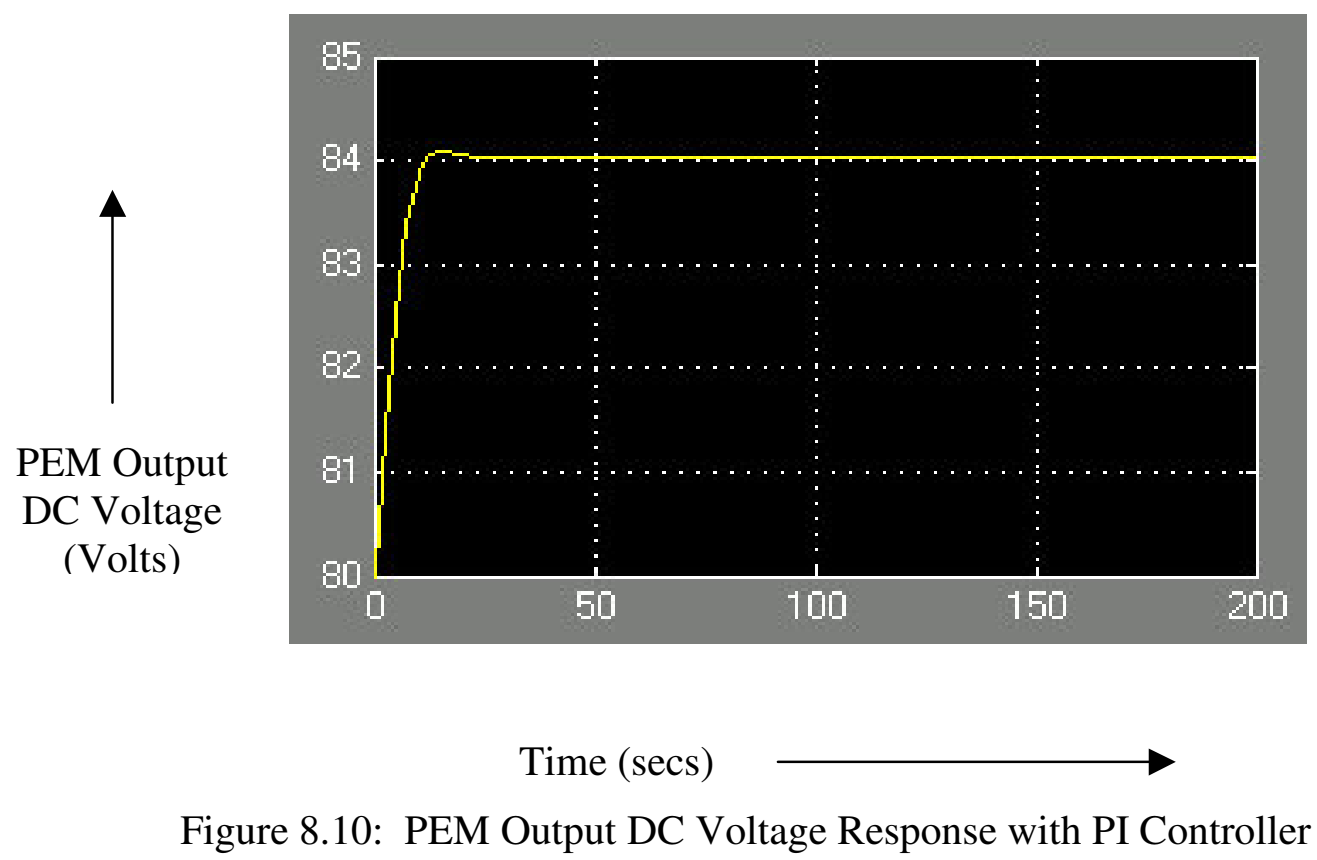

\subsection{Results Summary}

This thesis developed a dynamic model for a $45 \mathrm{~kW}$ PEM fuel cell with a variable stack temperature, a stack temperature distribution across the stack's cross sections and predicted the power generating characteristics for a PEM fuel cell stack. Stack temperature, which is a parameter in the model, is considered to be dynamic. Thus, more accurate performance of a PEM fuel cell can be simulated with dynamic changes in temperature using this model. 


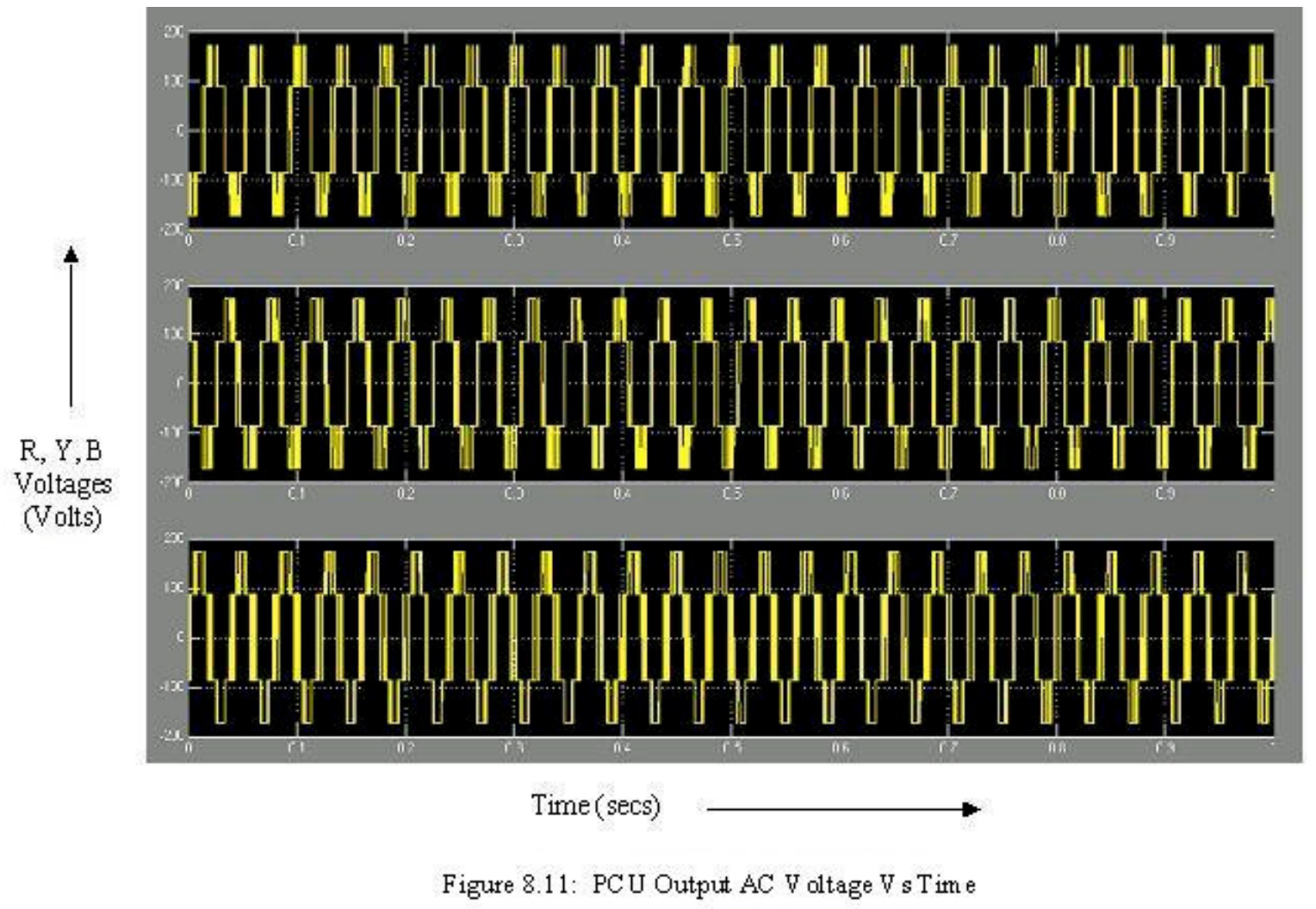


The stack temperature in a PEM can be monitored. Overheating of the fuel cell affects the performance of a fuel cell and may even permanently damage the successful operation of the fuel cell. This can be avoided because the temperature response of the fuel cell is simulated using this model. Results shown in this Thesis are within the operating temperature conditions of the PEM fuel cell. This successfully working model can be used to see how larger changes in line current might lead to temperatures higher than the operating temperatures, which eventually affects the life and performance of the PEM fuel cell. Results obtained from this model were compared with performance of real fuel cells.

This model is fast enough that it can be used in association with other CHP and PCU models. In the future, the PEM fuel cell life can be predicted as well as appropriate fuel cell cooling systems can be designed as the stack temperature distribution is modeled. This model is suitable for distributed generation for control purposes for both stand-alone mode and electric utility grid integrated mode. 


\section{Chapter 9. Contributions and Recommendations}

\subsection{Contributions}

This thesis identified a suitable type of fuel cell pertinent for use as a DG, developed model for this PEM fuel cell with variable temperature, modeled PCU and performed studies for the control of the PEM fuel cell system. The specific contributions of this thesis are:

1. Various types of fuel cells are available for power generation, namely, Phosphoric Acid Fuel Cell (PAFC), Solid Oxide Fuel Cell (SOFC), Molten Carbonate Fuel Cell (MCFC) and Proton Exchange Membrane (PEM) Fuel Cell. This research considered the use of distributed generation in a deregulated electric utility industry. Key aspects for such deregulation are providing peak shaving and connectivity to the electric utility grid. The distributed generator selected for this type of application must be fast in responding to changes in electric power demand, modular in size and reliable in operation. An assessment of possible DGs was conducted and the PEM fuel cell was selected for use in a deregulated electric utility industry.

2. The PEM fuel cell is a MIMO system with a large number of inputs and outputs. The dynamic modeling of such a system is complex and some model take a long time to run the simulations (e.g. CFD models). With a simpler mathematical model, simulation results could be obtained faster. But they need to be accurate. A simple dynamic model was developed in this thesis, with the right balance of accuracy and fastness suitable for control purposes pertinent to this research. 
3. Stack temperature and stack temperature distribution for a fuel cell was considered to be a constant in most of the previous models. This assumption was valid for shorter simulation time and during steady state conditions. To study the transient condition, stack temperature distribution had to be a variable. The model developed in this thesis successfully simulates the heat transfer and thermal dynamics inside the PEM fuel cell. Near accurate simulation of stack temperature is important because, temperature affects the performance and life of the fuel cell.

4. A PCU model developed and was shown that the output power from a fuel cell could be converted to interface with the electric utility grid.

5. A master-slave controller scheme was implemented in the PEM fuel cell system when not connected to the electric utility grid. The fuel flow rate of the fuel cell served as the master variable and inverter gain served as the slave variable. A PI control was used with the master controller and a P control was used with the slave controller. Performance of the fuel cell improved by $86 \%$ by the use of controllers.

\subsection{Achievements}

Results from this thesis had been used to make two IEEE technical publications. The first paper was titled "Proton Exchange Membrane Fuel Cell Dynamic Model for Distributed Generation Control Purposes". It was published in the IEEE North American Power Symposium (NAPS) 2002 Proceedings. This paper won the first prize paper award at NAPS conference for students. A second paper titled "Dynamic Heat Transfer Model Analyzing Power Generation 
Characteristics for a PEM Fuel Cell Stack" was published at the Southeastern Symposium for System Theory (SSST) 2003.

\subsection{Future Research}

1. A fuel cell system as a whole comprises other components such as humidifier, heat exchangers and reformer. Dynamic models of all these components can be developed to further study the performance of the fuel cell system.

2. The PEM fuel cell system can be connected to electric utility grid and analyzed.

3. The PCU design can be developed to consider the fuel cell as a current source.

4. The PCU performance can be further evaluated by designing the individual components of the PCU such as MOSFETs, line filters, resistors and capacitors. 


\section{REFERENCES}

[1] Piety, Pittsburgh Engineer Magazine, Engineers' Society of Western Pennsylvania, Fall 2001, p 2

[2] Douglas J. Smith, Power Engineering Magazine, March 1999, p 32

[3] Douglas J. Smith, Power Engineering Magazine, March 1999, p 33

[4] CD published by NETL, Morgantown, Fuel Cell Hand Book, October 2000, pp 1-3 to 1-33 and chapter 3

[5] CD published by NETL, Morgantown, Fuel Cell Hand Book, October 2000

[6] Michael D. Lukas, Kwang Y. Lee and Hossein Ghezel-Ayagh, Development of a Stack Simulation Model for Control Study on Direct Reforming Molten Carbonate Fuel Cell Power Plant, IEEE 1999, p 655

[7] Wei He, Dynamic Simulations of Molten Carbonate Fuel Cells, Delft University Press, 2000, p 3

[8] C. Marr and X. Li, An Engineering Model of a Proton Exchange Membrane Fuel Cell Performance, Springer-Verlag, 1998, pp 90-200

[9] Michael D. Lukas, Kwang Y. Lee and Hossein Ghezel-Ayagh, Development of a Stack Simulation Model for Control Study on Direct Reforming Molten Carbonate Fuel Cell Power Plant, IEEE 1999, p 653

[10] Michael D. Lukas, Kwang Y. Lee and Hossein Ghezel-Ayagh Reduced Order Dynamic Model of Carbonate Fuel Cell System for Distributed Generation Control, IEEE 2000, pp 1965-1969

[11] James Larminie, Andrew Dicks, Fuel Cell Systems Explained, John Wiley \& Sons, Inc., 2000, p 302

[12] W. He and Q. Chen, Three-dimensional Simulation of a Molten Carbonate Fuel Cell Stack Using Computational Fluid Dynamics Technique, Journal of Power Sources 55, 1995, p 25-32

[13] Joon-Ho Koh, Byoung Sam Kang and Hee Chun Lim, Analysis of Temperature and Pressure Fields in Molten Carbonate Fuel Cell Stacks, AIChE Journal, Vol. 47, No. 9, p 1941-1954

[14] Muhammad Harunur Rashid, Power Electronics, Prentice Hall, 1988 
[15] Michael D. Lukas, Kwang Y. Lee and Hossein Ghezel-Ayagh, Operation and Control of Direct Reforming Fuel Cell Power Plant, IEEE Journal, 2000, p 526

[16] James Larminie, Andrew Dicks, Fuel Cell Systems Explained, John Wiley \& Sons, Inc., 2000, p 66

[17] James Larminie, Andrew Dicks, Fuel Cell Systems Explained, John Wiley \& Sons, Inc., 2000, pp 69-81

[18] Dale E. Seborg, Thomas F. Edgar and Duncan A. Mellichamp, Process Dynamics and Controls, John Wiley and Sons, 1996, pp 412-434

[19] James Larminie, Andrew Dicks, Fuel Cell Systems Explained, John Wiley \& Sons, Inc., 2000, pp 201-205

[20] Wei He, Dynamic Simulations of Molten Carbonate Fuel Cells, Delft University Press, 2000, p 45

[21] James Larminie, Andrew Dicks, Fuel Cell Systems Explained, John Wiley \& Sons, Inc., 2000, pp 63-65

[22] Michael D. Lukas, Kwang Y. Lee and Hossein Ghezel-Ayagh, Development of a Stack Simulation Model for Control Study on Direct Reforming Molten Carbonate Fuel Cell Power Plant, IEEE 1999, 0885-8969, p 1653

[23] Michael D. Lukas, Kwang Y. Lee and Hossein Ghezel-Ayagh Reduced Order Dynamic Model of Carbonate Fuel Cell System for Distributed Generation Control, IEEE 2000, p 1795

[24] Michael D. Lukas, Kwang Y. Lee and Hossein Ghezel-Ayagh, Development of a Stack Simulation Model for Control Study on Direct Reforming Molten Carbonate Fuel Cell Power Plant, IEEE 1999, 0885-8969, p 1655

[25] James Larminie and Andrew Dicks, Fuel Cell Systems Explained, John Wiley and Sons, Ltd., 2000, p 302

[26] James Larminie and Andrew Dicks, Fuel Cell Systems Explained, John Wiley and Sons, Ltd., 2000, p 302

[27] Michael J. Moran, Fundamentals of Engineering Thermodynamics, WSE Press, 1999

[28] Muhammad Harunur Rashid, Power Electronics, Prentice Hall, 1988, p 227

[29] Muhammad Harunur Rashid, Power Electronics, Prentice Hall, 1988, p 243 
[30] J. C. Amphlett, R. F. Mann, B. A. Peppley, P.R. Roberge and A. Rodrigues, A Model Predicting Transient Responses of Proton Exchange Membrane Fuel Cells, Journal of Power Sources 1996, p 184

[31] J. Hamelin, K. Agbossou, A. Laperriere, F. Laurencelle and T. K. Bose, Dynamic Behavior of a PEM Fuel Cell Stack for Stationary Applications, International Journal of Hydrogen Energy 2001, p 626

[32] J. C. Amphlett, R. F. Mann, B. A. Peppley, P.R. Roberge and A. Rodrigues, A Model Predicting Transient Responses of Proton Exchange Membrane Fuel Cells, Journal of Power Sources 1996, p 187

[33] Wei He, Dynamic Simulations of Molten Carbonate Fuel Cells, Delft University Press, 2000, p 68

[34] Wei He, Dynamic Simulations of Molten Carbonate Fuel Cells, Delft University Press, 2000, p 57

[35] Wei He, Dynamic Simulations of Molten Carbonate Fuel Cells, Delft University Press, 2000, p 71 


\section{Appendix A. PEM Fuel Cell Non-linear Modeling using Simulink}

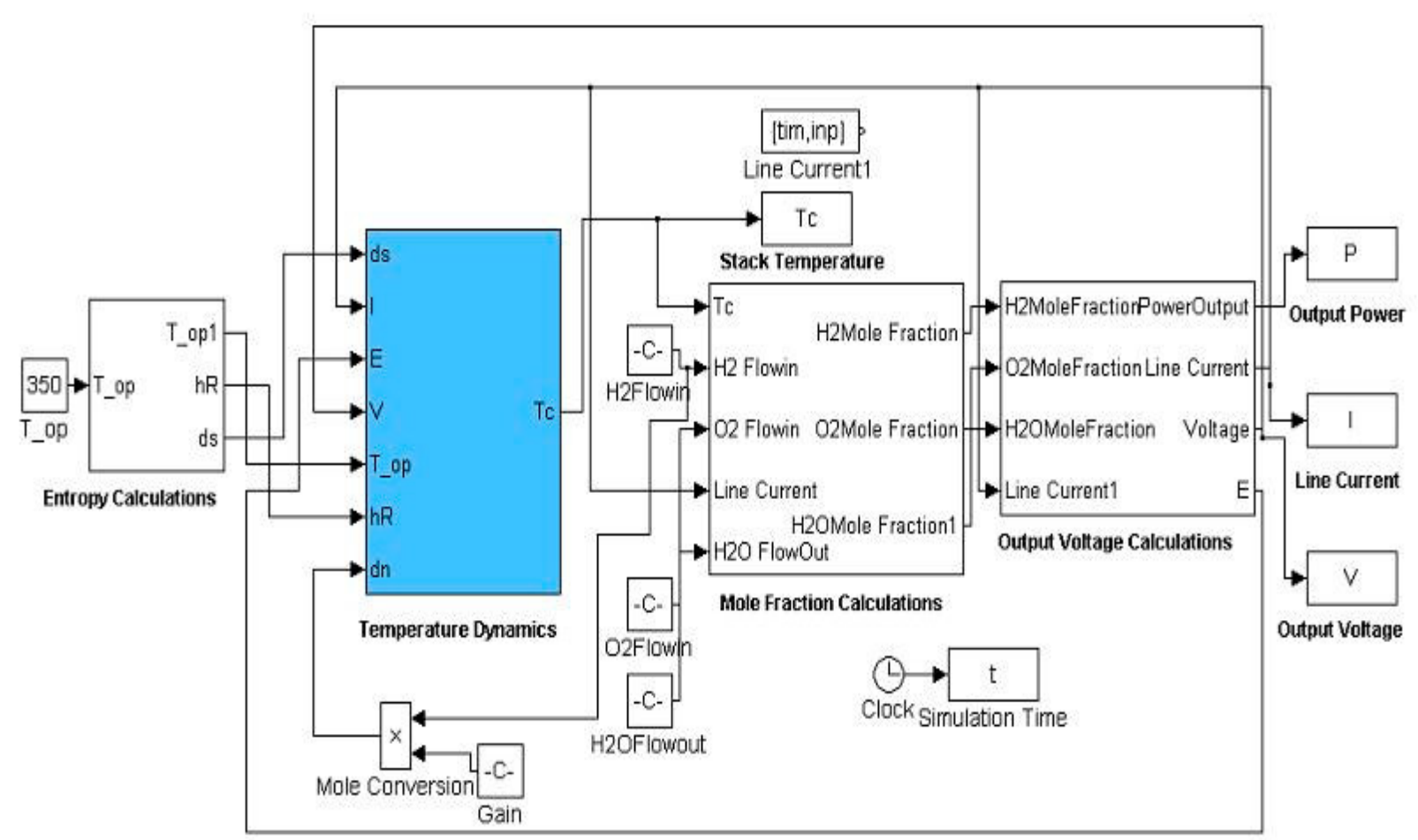

Figure A.1: Non-linear Model for a PEM Fuel Cell System in Simulink

Figure A.1 shows the developed non-linear PEM fuel cell model in Simulink. Inputs to the model are input hydrogen flow rate, input oxygen flow rate, line current and operating temperature. The model outputs voltage and output power can be manipulated using the line current. This model uses the equations described in Chapter 5 of this thesis. Underneath the Simulink top layer are the various equations used and they are shown in the subsequent Figures used in this Chapter. 


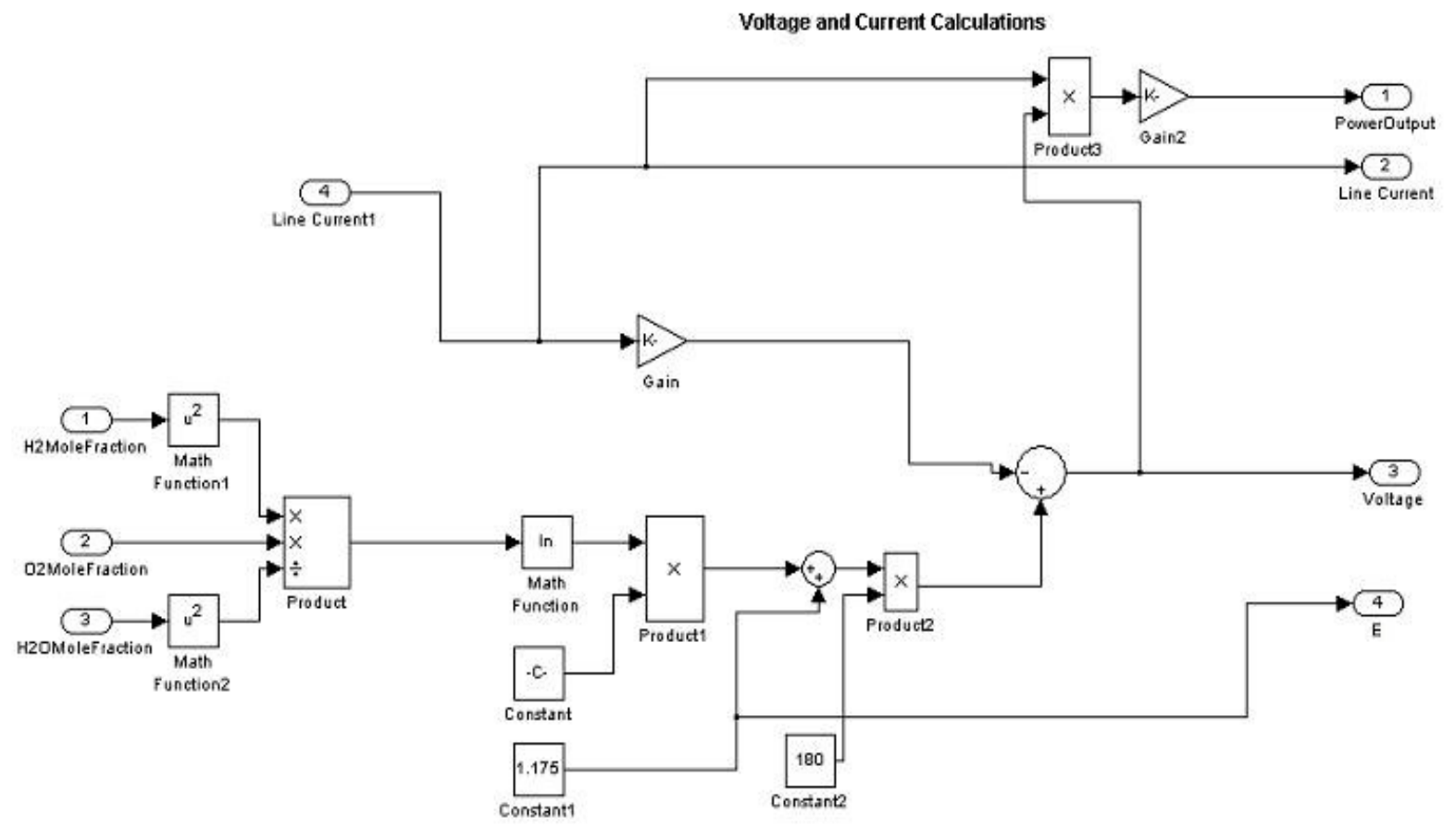

Figure A.2: Voltage and Current Calculations in Simulink

Figure A.2 shows the output voltage and output power. This figure is developed using the Nernst Equation which is described in Chapter 5 as Equation 5.8. Inputs to the model are hydrogen mole fraction, oxygen mole fraction and exit water mole fraction.

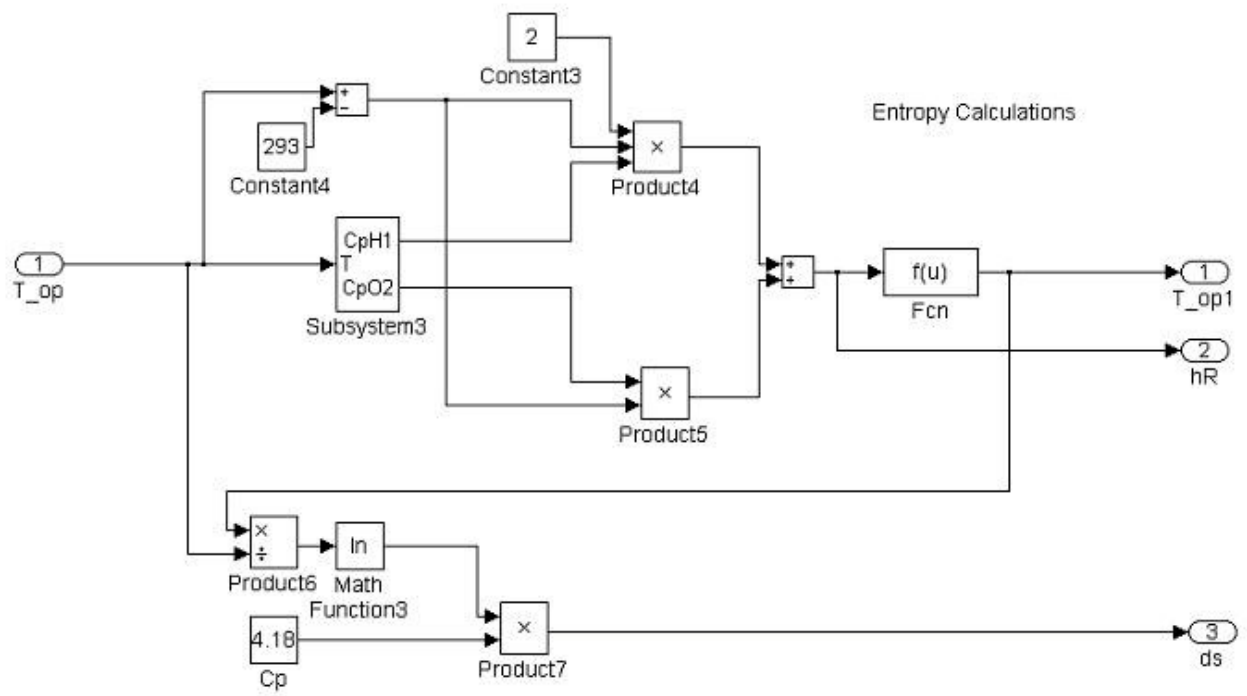

Figure A.3: Entropy Calculations in Simulink 
Figure A.3 shows the entropy calculations using Equation 5.10. Operating temperature of the stack becomes the initial input for this block.

\section{Mole Fraction Calculations}

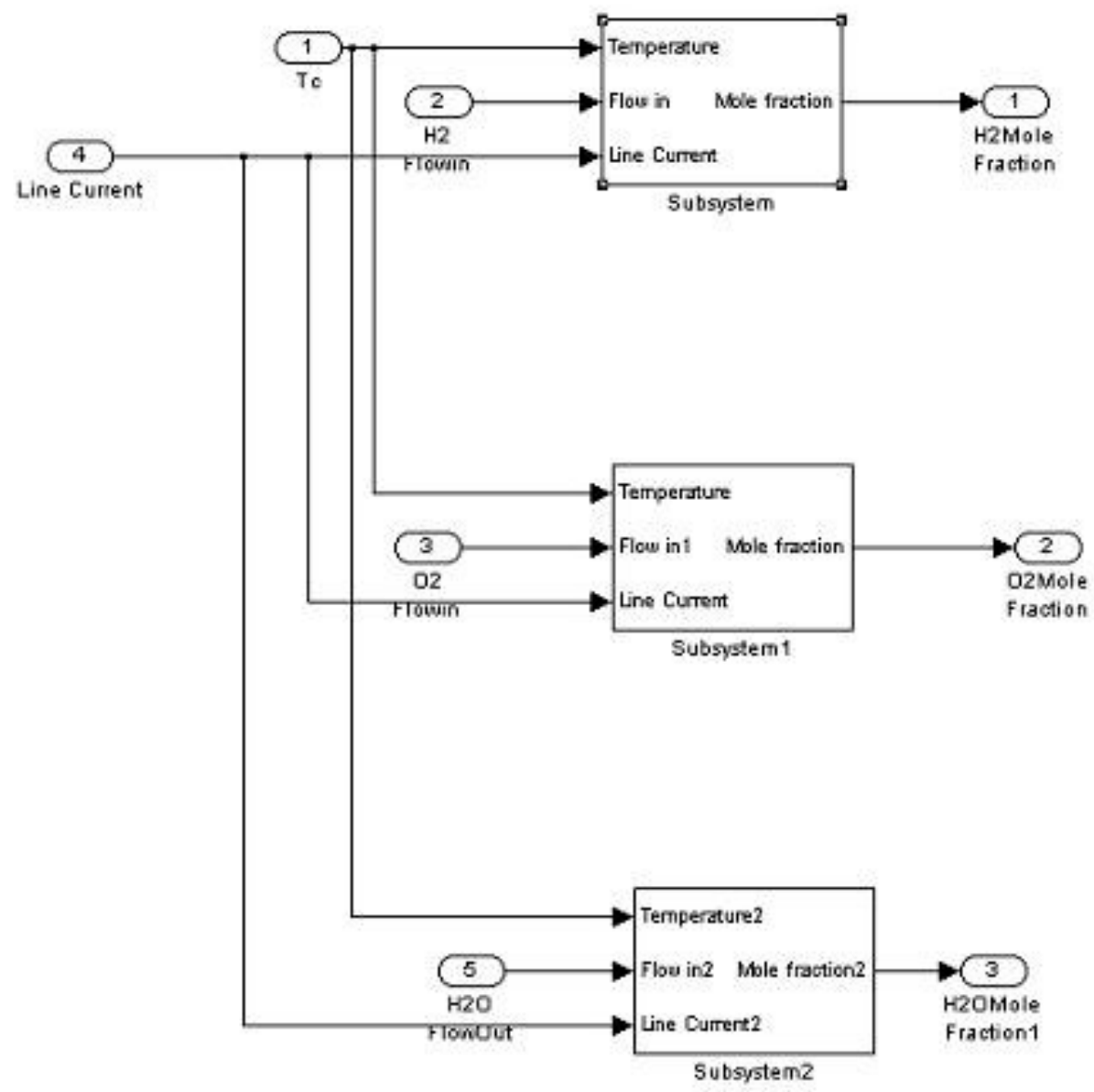

Figure A.4: Mole Fraction Calculations in Simulink

Figure A.4 shows the mole fraction calculations that are needed to calculate the Nernst Equation. These calculations are based on the component balance equation, which is, Equations 5.5, 5.6 and 5.7. 


\section{Appendix B. PEM Heat Transfer and Temperature Distribution Modeling using MATLAB Programming}

Shown below is the MATLAB code for calculating the temperature dynamics and heat transfer that takes place inside the PEM fuel cell. This code uses Equation 5.9, Equation 5.11 and Equation 5.12

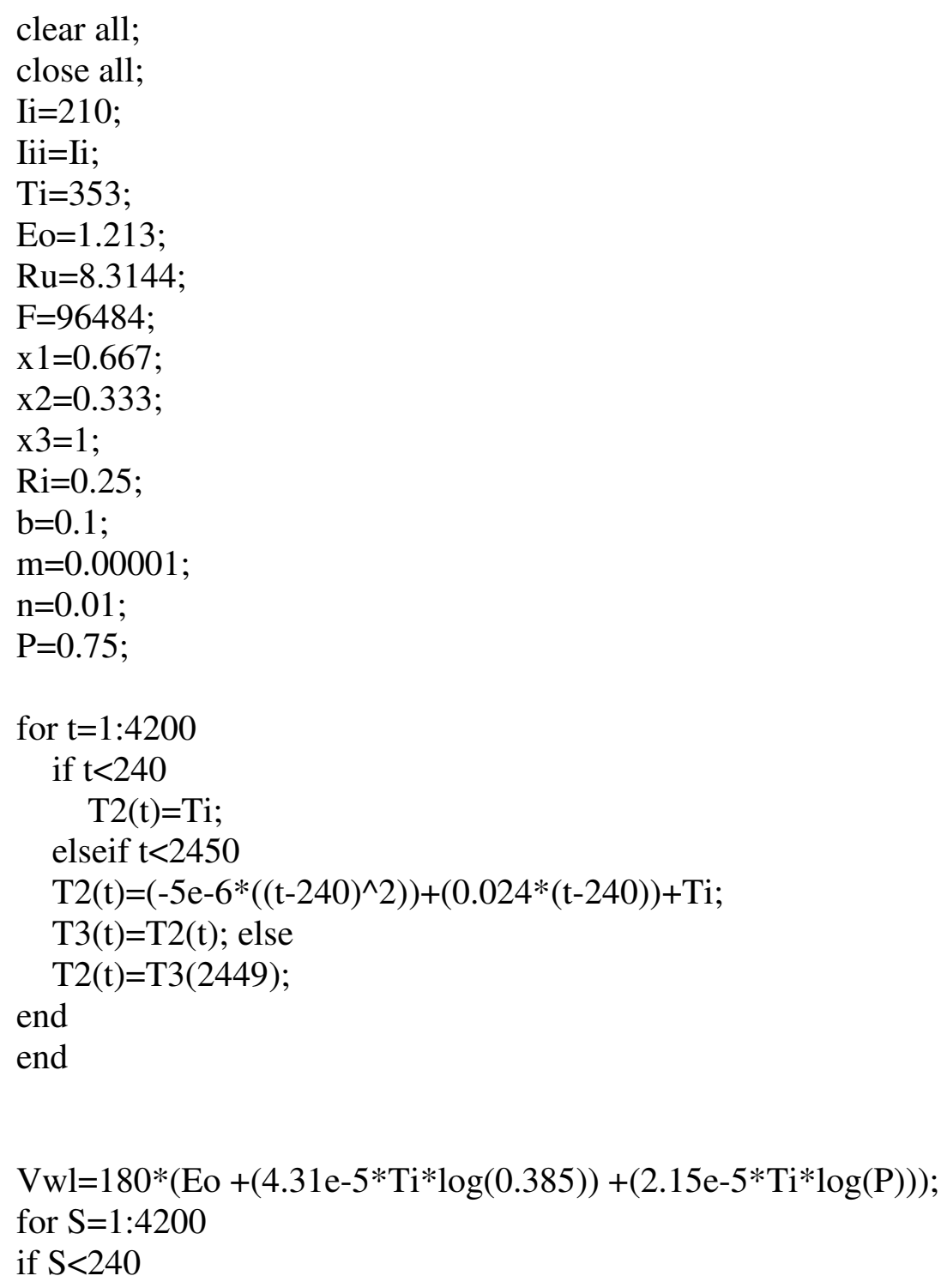




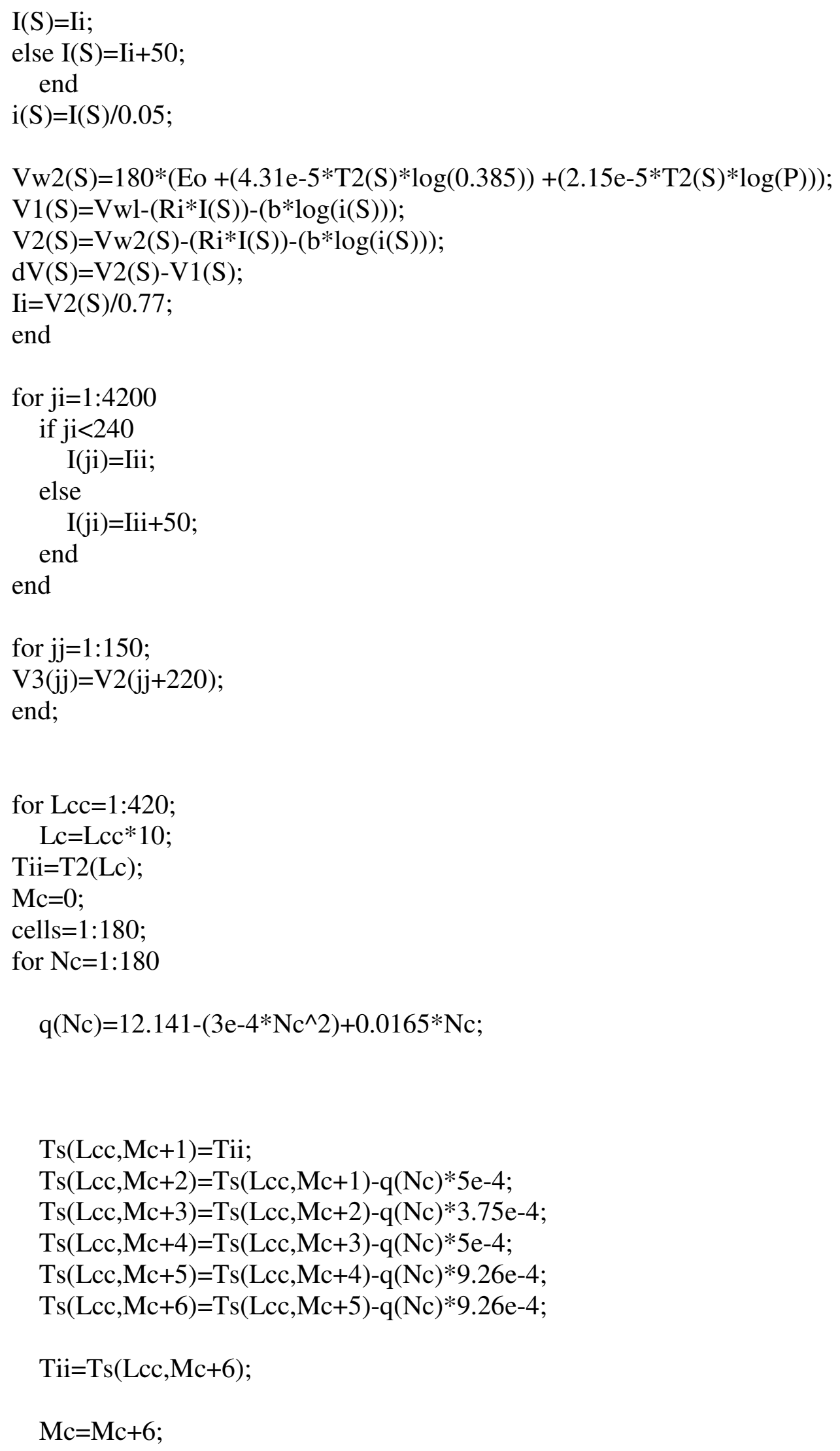

$\operatorname{Ts}(\mathrm{Lcc}, \mathrm{Mc}+1)=\mathrm{Tii}$

$\mathrm{Ts}(\mathrm{Lcc}, \mathrm{Mc}+2)=\mathrm{Ts}(\mathrm{Lcc}, \mathrm{Mc}+1)-\mathrm{q}(\mathrm{Nc}) * 5 \mathrm{e}-4$;

$\mathrm{Ts}(\mathrm{Lcc}, \mathrm{Mc}+3)=\mathrm{Ts}(\mathrm{Lcc}, \mathrm{Mc}+2)-\mathrm{q}(\mathrm{Nc}) * 3.75 \mathrm{e}-4$;

$\mathrm{Ts}(\mathrm{Lcc}, \mathrm{Mc}+4)=\mathrm{Ts}(\mathrm{Lcc}, \mathrm{Mc}+3)-\mathrm{q}(\mathrm{Nc}) * 5 \mathrm{e}-4$;

$\mathrm{Ts}(\mathrm{Lcc}, \mathrm{Mc}+5)=\mathrm{Ts}(\mathrm{Lcc}, \mathrm{Mc}+4)-\mathrm{q}(\mathrm{Nc}) * 9.26 \mathrm{e}-4$

$\mathrm{Ts}(\mathrm{Lcc}, \mathrm{Mc}+6)=\mathrm{Ts}(\mathrm{Lcc}, \mathrm{Mc}+5)-\mathrm{q}(\mathrm{Nc}) * 9.26 \mathrm{e}-4$;

$\mathrm{Tii}=\mathrm{Ts}(\mathrm{Lcc}, \mathrm{Mc}+6)$;

$\mathrm{Mc}=\mathrm{Mc}+6$ 
end;

end;

time $=100 *(1: 42)$;

cellsection $=(1: 1080)$;

figure(1);

$\operatorname{plot}(\mathrm{I}, \mathrm{k}$ ')

title('Step change in Input Line Current');

xlabel('Time (secs)');

ylabel('Current (amps)');

axis([0 42000300$])$;

figure(2);

plot(T2,'b')

title('Stack Temperature Response');

xlabel('Time (secs)');

ylabel('Temperature (deg. Kelvin)');

axis([0 42000420$])$;

figure(3);

$\operatorname{plot}\left(\mathrm{V} 2, \mathrm{~b}^{\prime}\right)$

title('Stack Voltage Response');

xlabel('Time (secs)');

ylabel('Voltage (Volts)');

$\operatorname{axis}\left(\left[\begin{array}{llll}0 & 4200 & 0 & 170\end{array}\right]\right)$;

figure(4);

$\operatorname{plot}\left(\mathrm{V} 3, \mathrm{k}^{\prime}\right)$

title('Stack Voltage Response - Zoomed Version');

xlabel('Time (secs)');

ylabel('Voltage (Volts)');

axis([0 150140170$])$;

figure(5);

mesh(cellsection,time,Ts)

title('Stack Temperature Distribution in a Stack - 3D Perspective');

xlabel('Stack Cross Section (no units)');

ylabel('Time (secs)');

zlabel('Stack Temperature per Cross Section (deg. Kelvin)'); 


\section{Appendix C. PEM Fuel Cell Control using Simulink}

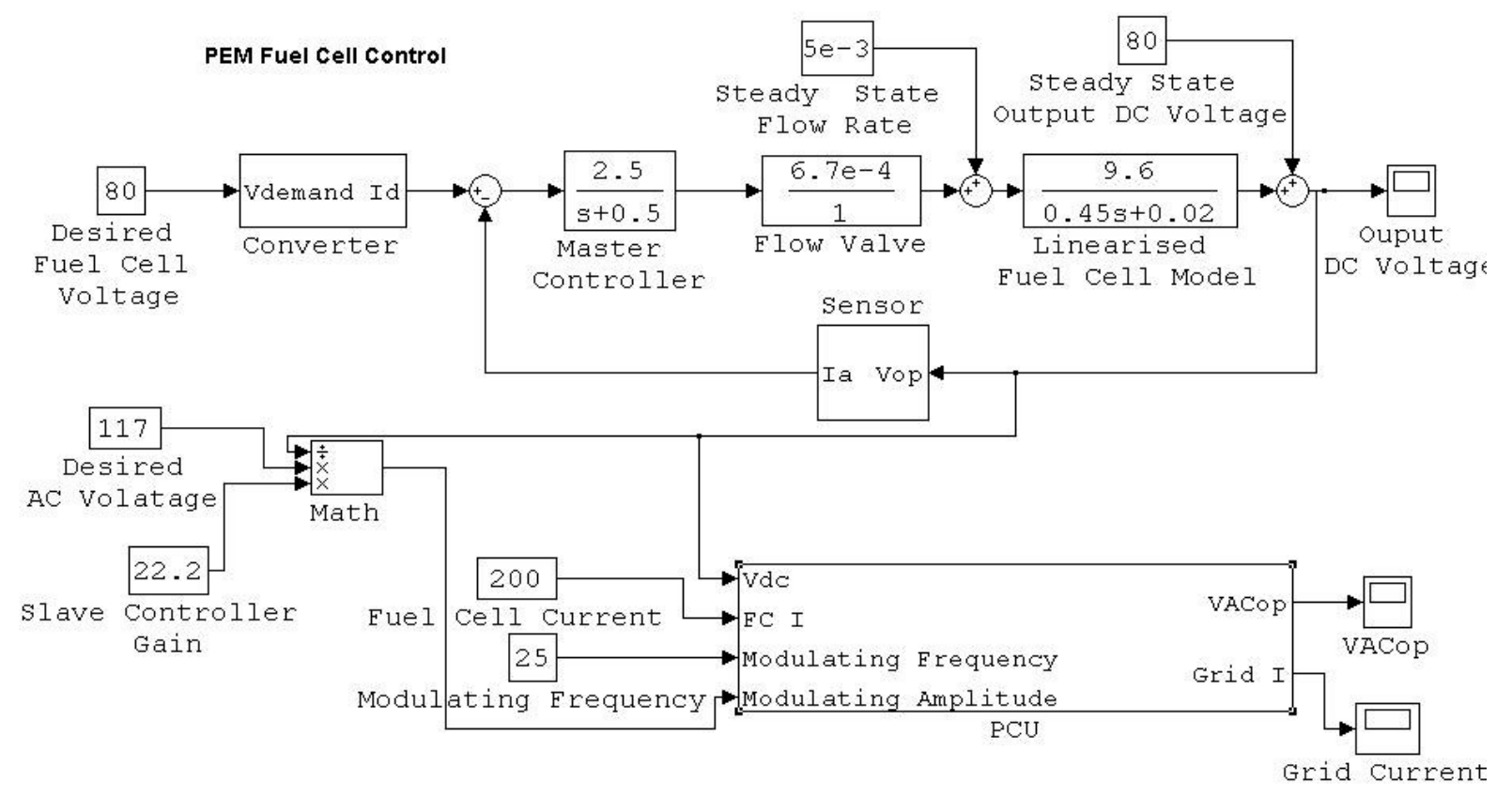

Figure C.1: Linear PEM Fuel Cell System Model in Simulink

Figure C.1 shows the linear PEM fuel cell model in Simulink based on Equations 5.13,

7.1 and 7.2. Desired DC voltage is given as the input to the voltage-current converter. The current signal from the converter is compared with the feed back current signal from the sensor and the current error signal is calculated. This error signal becomes the input for the Master Controller. Output signal from the master controller actuates the flow valve and the hydrogen molar flow rate becomes the input for the Linearized PEM fuel cell model discussed in Section 6.6.2.

Figure C.2 shows the PCU model in Simulink. This model is based on Equations 6.1 to 6.6. Figure C.3 shows the inverter model in Simulink developed from Reference 29. 


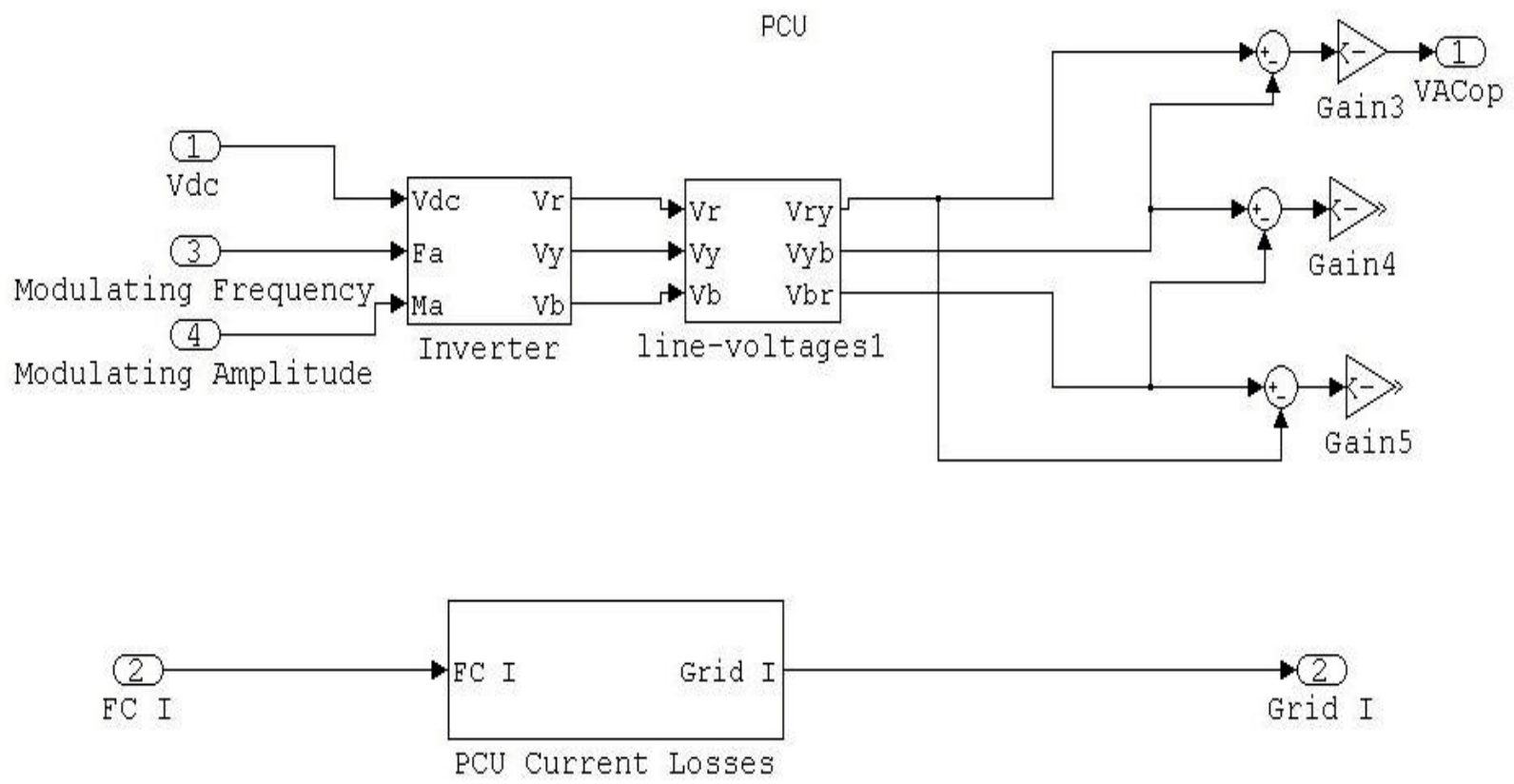

Figure C.2: PCU Model in Simulink

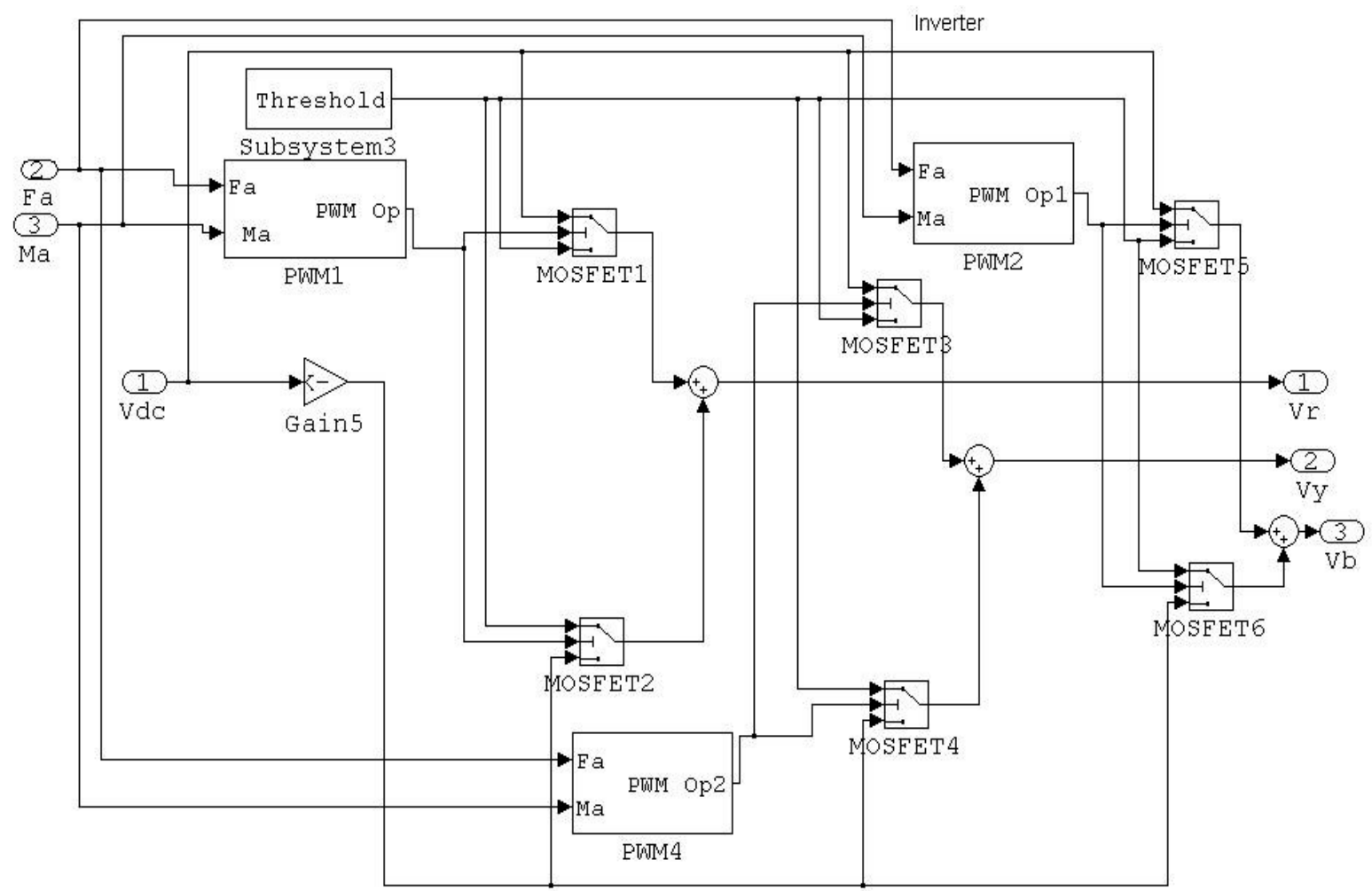

Figure C.3: Inverter Model in Simulink 


\section{Appendix D. PEM Fuel Cell System}

\section{D.1 Introduction}

The schematic diagram of a PEM fuel cell balance of plant is shown in Figure D.1 [6], and [15]. Whenever the PEM fuel cell system was referred to in this thesis, it refers to the system comprising of the PEM fuel cell, control valves, PCU and controllers. This is shown in the dotted box in Figure D.1. Feed water was treated for solid impurities and other chemicals such as sodium chloride. It was pumped to a preheater, where the water is preheated to $194{ }^{\circ} \mathrm{F}$. The water is then super-heated to $842^{\circ} \mathrm{F}$ in the super heater. This steam is used to feed the humidifier and the reformer.

Natural gas is treated to remove gaseous ingredients such as sulfur and carbon. Otherwise, these ingredients will affect the performance of the PEM fuel cell. The treated natural gas was preheated to $249^{\circ} \mathrm{F}$ and fed to the reformer. The reformer converts the natural gas into hydrogen, in a series of chemical reactions with steam. Fuel for the PEM fuel cell (hydrogen) was then stored in a hydrogen buffer tank. The fuel was then humidified using a humidifier. This fuel was then fed to the anode of the PEM fuel cell, through the fuel control valve.

Air was also treated, compressed and heated in a catalytic burner. This heated air is fed to the cathode of the PEM fuel cell, through the air control valve. The output DC current was conditioned for voltage using the Power Conditioning Unit. This current is then fed to the electric grid. 


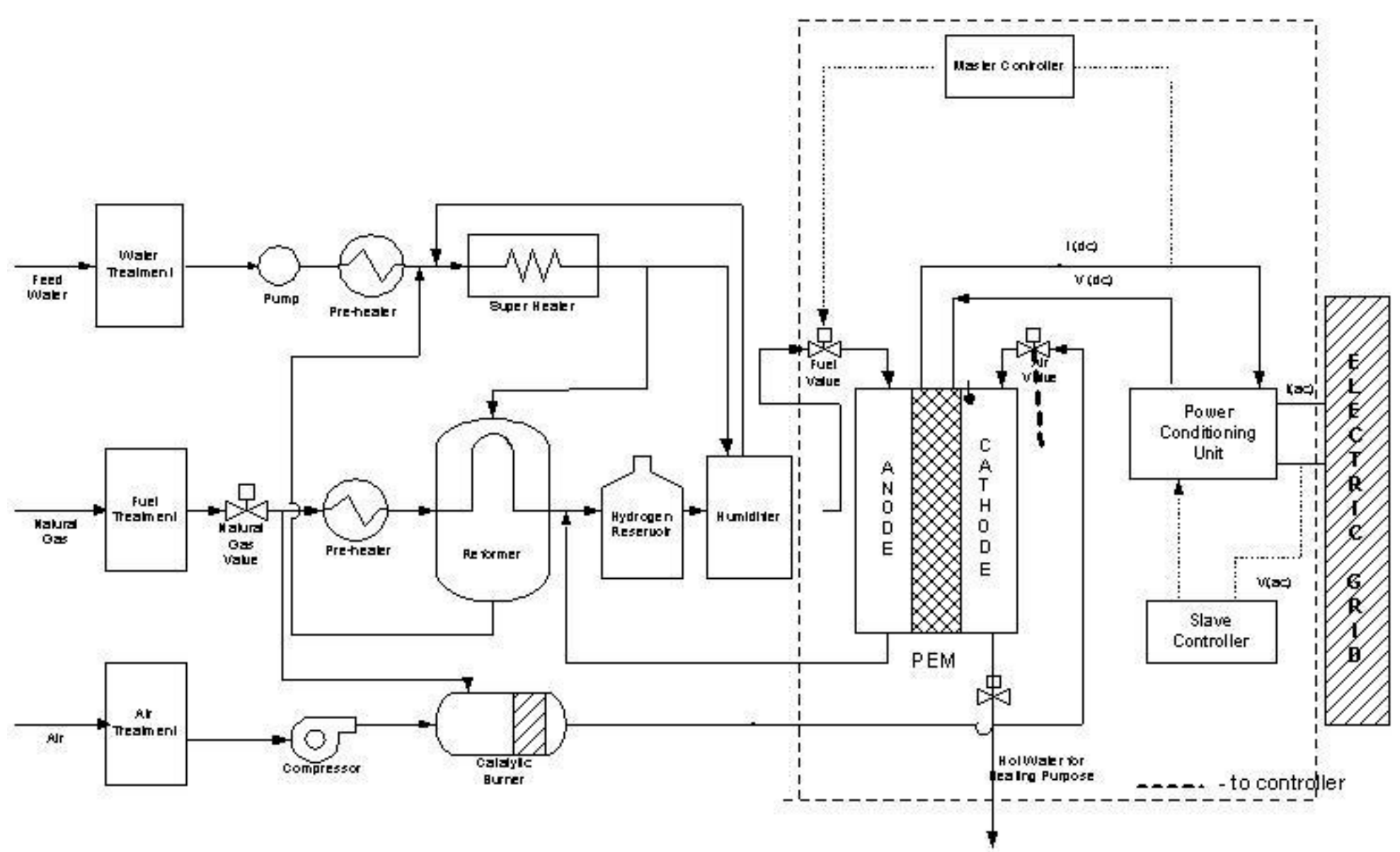

Figure D.1: Schematic Diagram for a PEM F uel Cell System 


\section{D.2 Humidifier}

Water management is very important [17] in the case of a PEM fuel cell. The porous electrodes used in a PEM should always be kept moist to keep the reaction happening. Otherwise, the reaction will slow down or stop depending upon the level of dehydration inside the fuel cell.

On the other hand, flooding of the electrodes will also create problems inside the PEM fuel cell. Flooding of the electrodes leads to the dilution of reactant gases. The electrode surface should be kept intact with the electrolyte surface to keep the reaction happening. Flooding may affect this intactness. Moreover, flooding increases the losses due to concentration polarization.

There should always be a level of moisture inside the PEM fuel cell. Any unbalance will result in the poor performance of the PEM. Humidification process in a PEM fuel cell can be broadly classified into external humidification and internal humidification. In external humidification, one uses a wick to drain or supply water through capillary action. Again, there are several ways of internally humidifying a PEM fuel cell that are found in the literature. One method is to pass a stream of thin water on the surface of a PEM electrode. Another method is to internally let water bleed at several points of the electrode assembly. A method for direct injecting of water at the fuel flow [17] can be used. This method is represented in Figure D.2. Fuel enters the inlet of the humidifier. Water is injected to the fuel pipe as controlled by a control valve. Sensors sense the level of humidity and stoichiometry, and sends control signal to the controller. The control valve is either in the ON stage or OFF stage, according to the criteria shown in Table D.1. 
Table D.1: Conditions for Humidifier ON/OFF Stages

\begin{tabular}{|l|c|c|}
\hline & Condition for ON Stage & Condition for OFF Stage \\
\hline Humidity & $<70 \%$ & $>70 \%$ \\
\hline Stoichiometry & $<240$ & $>240$ \\
\hline
\end{tabular}

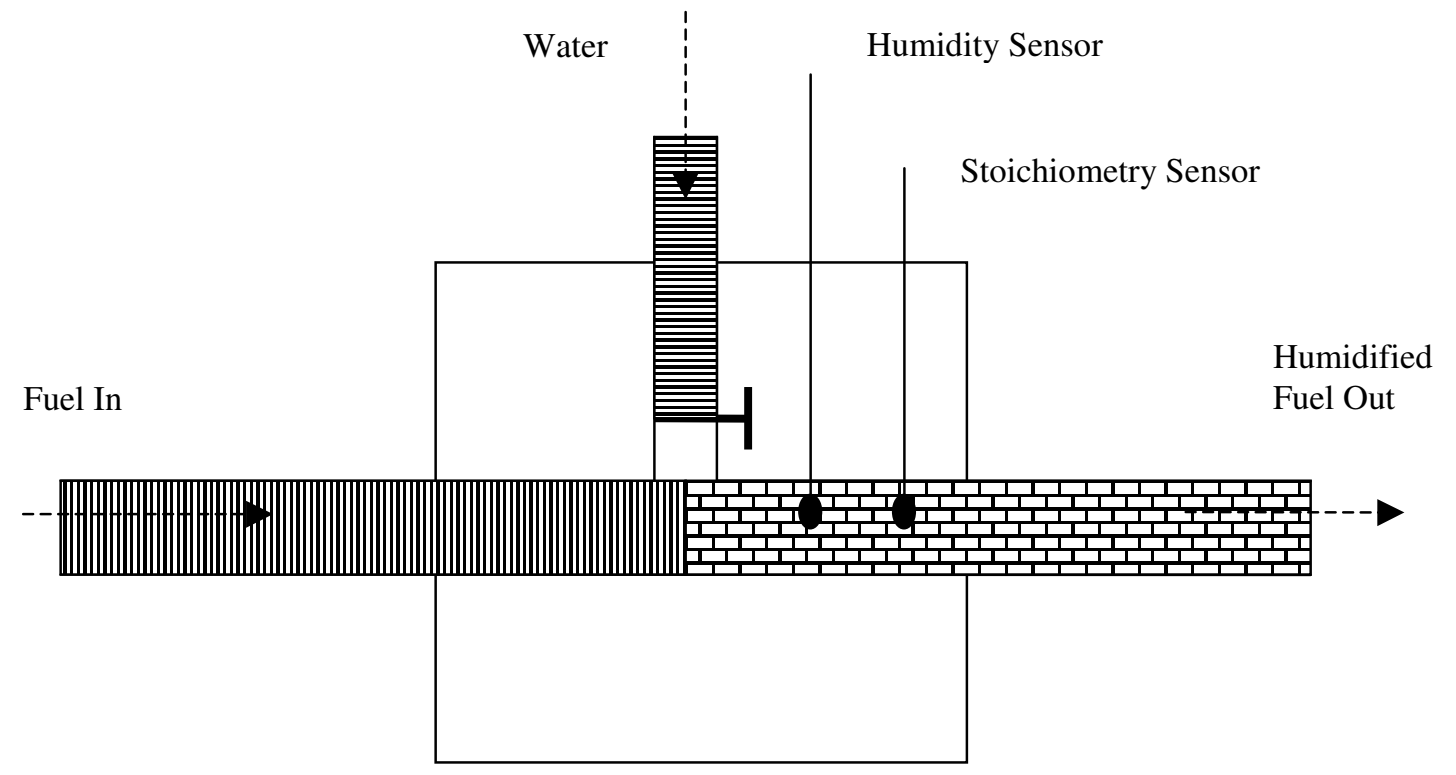

Figure D.2: Schematic Diagram of a Humidifier for a PEM Fuel Cell

\section{D.3 Reformer}

The input fuel for a PEM system is natural gas. Natural gas will have to be converted to hydrogen and this hydrogen is fed into the PEM fuel cell system. Natural gas combines with steam to produce hydrogen. This reaction is endothermic and takes place at $932^{\circ} \mathrm{F}$.

The reactions that takes place inside a reformer [19] is described in Equation D.1 and Equation D.2. 


$$
\begin{aligned}
& \mathrm{CH}_{4}+\mathrm{H}_{2} \mathrm{O} \rightarrow \mathrm{CO}+3 \mathrm{H}_{2} \\
& \mathrm{CO}+\mathrm{H}_{2} \mathrm{O} \rightarrow \mathrm{CO}_{2}+\mathrm{H}_{2}
\end{aligned}
$$

There are two types of reformers. One is the internal type and the other is the external type. The use of an internal type of reformer is not possible for a PEM fuel cell, as the operating temperature of a PEM fuel cell is $176^{\circ} \mathrm{F}$. In high temperature fuel cells, reforming could be carried out inside the fuel cell itself as the temperatures are higher than $932^{\circ} \mathrm{F}$. An external type reformer can be modeled based on thermodynamic theory and could be used in the PEM balance of plant.

\section{D.4 Hydrogen Buffer Tank}

Reformer takes several minutes to generate hydrogen from natural gas (time order 2 to 3 minutes). Thus, reformer operation is slower compared to fuel cell operation. Hence, a hydrogen buffer tank is included in between the reformer and humidifier.

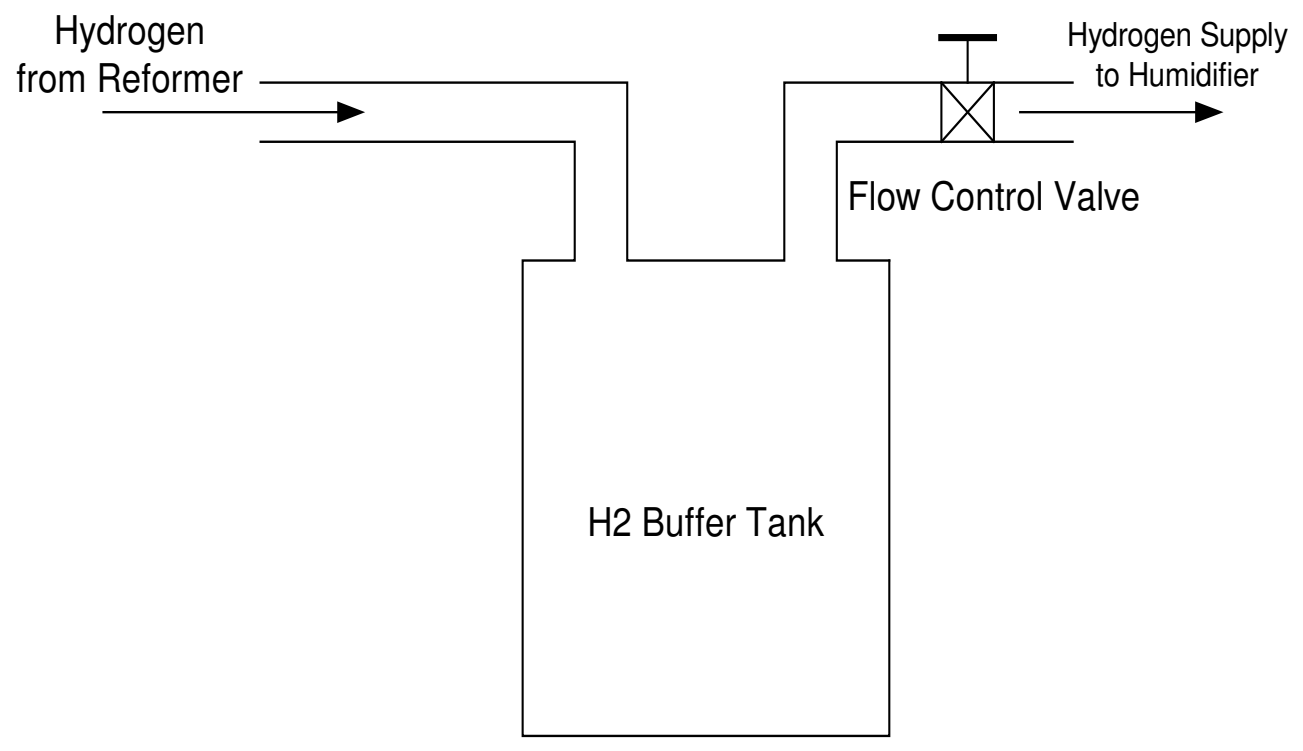

Figure D.3: Schematic Diagram of a Hydrogen Buffer Tank 
Figure D. 3 shows a schematic diagram of a hydrogen buffer tank. This tank serves as the instant source of hydrogen for the PEM fuel cell. The tank has an inlet for incoming processed hydrogen gas from the reformer. Hydrogen is stored as a buffer for fuel cell fuel. The tank is designed such that it can hold enough hydrogen to feed the fuel cell running under peak operating conditions for 30 minutes. This ensures $100 \%$ availability of hydrogen for continuous fuel cell operation. Hydrogen supplied to the fuel cell via humidifier is controlled by means of a hydrogen flow control valve, which is described in Section D.4. 